\title{
THE FINAL PHASES OF THE OLIVAL DO SENHOR DOS MÁRTIRES NECROPOLIS (ALCÁCER DO SAL, PORTUGAL): THE ROMAN REPUBLICAN MATERIAL
}

\author{
LAS FASES FINALES DE LA NECRÓPOLIS DEL OLIVAL DO SENHOR DOS MÁRTIRES \\ (ALCÁCER DO SAL, PORTUGAL): EL MATERIAL ROMANO REPUBLICANO
}

\author{
FRANCISCO B. GOMES* / CATARINA ALVES**
}

\begin{abstract}
This contribution aims to present an ensemble of material of Roman Republican chronology exhumed in the necropolis of Olival do Senhor dos Mártires (Alcácer do Sal, Portugal). In order to assess the importance of this period in the overall phasing of the site, this ensemble - comprising black gloss pottery, amphorae, unguentaria and a terracotta figurine - is studied from a chronological, typological and functional point of view. The resulting framework of reference allows to propose that this area was probably continually used as a burial ground throughout the Republican period (mid- $2^{\text {nd }}$ to late $1^{\text {st }}$ centuries BCE), thus putting the apparent hiatus between the Late Iron Age and the Imperial phases of the necropolis in perspective.
\end{abstract}

Keywords: Olival do Senhor dos Mártires; Roman Republican period; black gloss pottery (BGP); amphorae; unguentaria.

\section{INTRODUCTORY REMARKS: CONTEXT, SCOPE AND AIMS}

Since the late $19^{\text {th }}$ century the area surrounding the hermitage of Senhor dos Mártires, approximately one

\footnotetext{
* UNIARQ-Centro de Arqueologia da Universidade de Lisboa Fundação para a Ciência e Tecnologia. Faculdade de Letras da Universidade de Lisboa, Alameda da Universidade, 1600-214, Lisboa, Portugal; Correo-e: franciscojbgomes@gmail.com.
}

Resumen: La presente contribución pretende presentar un conjunto de materiales de cronología romana republicana exhumado en la necrópolis del Olival do Senhor dos Mártires (Alcácer do Sal, Portugal). De cara a evaluar la importancia de este período en la secuencia del yacimiento, dicho conjunto, que incluye cerámicas de barniz negro, ánforas, ungüentarios y una terracota, fue objeto de una valoración cronológica, tipológica y funcional. El cuadro de referencia resultante permite proponer que esta área probablemente conoció una utilización funeraria continuada durante el período republicano (mediados del siglo II a finales del I a.n.e.), lo que permite cuestionar el aparente hiato entre la fase de la II Edad del Hierro y la romana imperial.

Palabras clave: Olival do Senhor dos Mártires; período romano republicano; cerámicas de barniz negro; ánforas; ungüentarios.

kilometre to the West of the castle and historic centre of Alcácer do Sal (Portugal) (fig. 1), has been recognized as an important funerary area with a long diachrony of use. In fact, and if most of the research regarding this necropolis has been focused on its pre-roman phases

** UNIARQ-Centro de Arqueologia da Universidade de Lisboa; Fundação para a Ciência e Tecnologia. Faculdade de Letras da Universidade de Lisboa, Alameda da Universidade, 1600-214, Lisboa, Portugal; Correo-e: catarina4alves@gmail.com. 


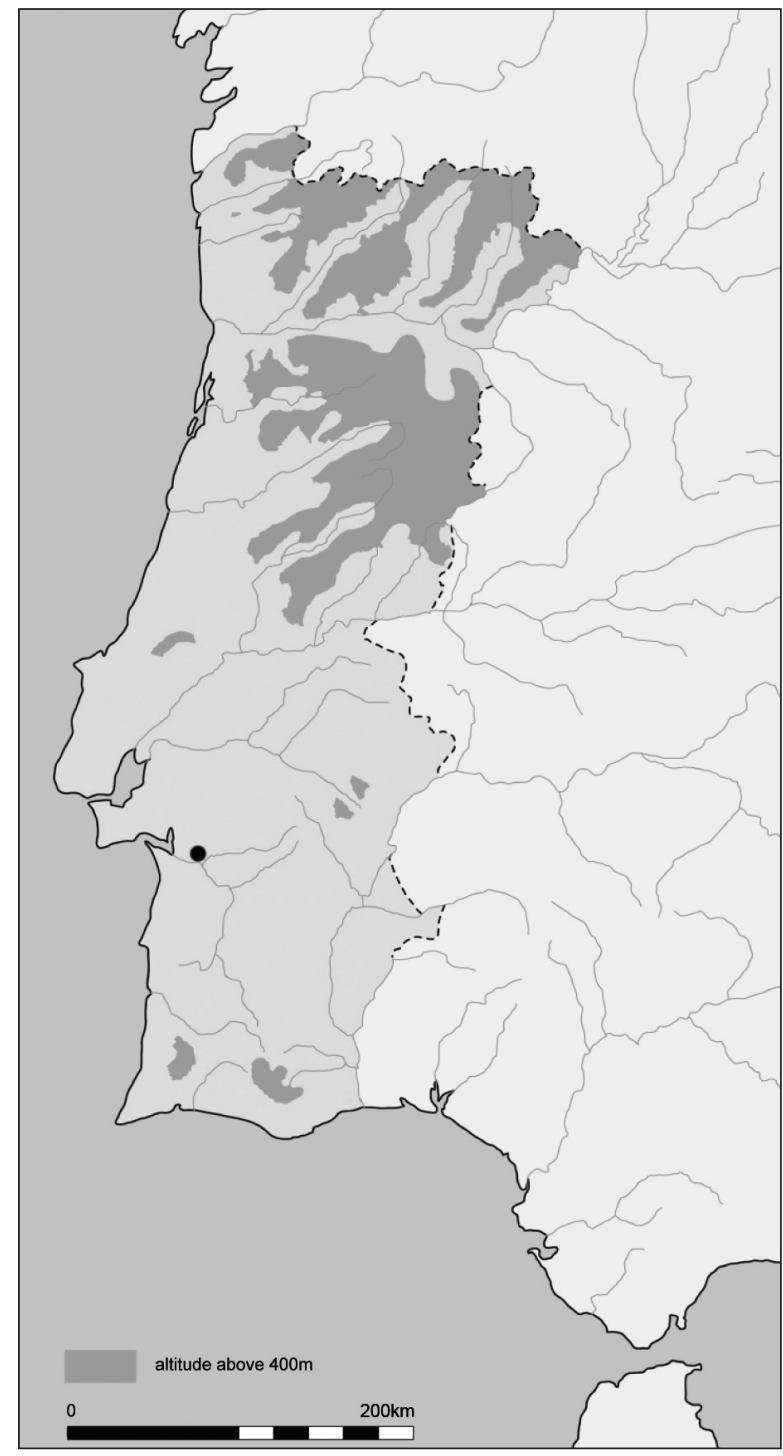

Figure 1. Location of Alcácer do Sal in the Portuguese territory (cartographic base by Professor V. S. Gonçalves).

(Correia 1925, 1928; Schüle 1969; Paixão 1970; 1983; Fabião 1998: 350-369; Arruda 1999-2000: 72-86; Gomes 2015), mainly due to the rich and complex panorama offered by the Iron Age tombs, it has been known since at least 1895 that the same area was also used as a necropolis during Roman times, with abundant material pertaining to the early imperial phases having been found during agricultural works (Baptista 1895).

This fact notwithstanding, during most of the $20^{\text {th }}$ century research regarding the Roman occupation of this area was practically inexistent, and it was not until the late 1960 's that the actual presence of funerary contexts pertaining to this period was documented during the excavations conducted by A. Cavaleiro Paixão (1970: 92), having however deserved little attention in the volume dedicated to his earliest campaigns.

It was nonetheless with this work that a long-standing historiographical assumption came to be accepted - A. Cavaleiro Paixão established in fact the division of the archaeological area surrounding the aforementioned hermitage of Senhor dos Mártires in two different archaeological sites: the by then already well-known Olival do Senhor dos Mártires (OSM), which would correspond to the area of the Iron Age necropolis, and the Azinhaga do Senhor dos Mártires (ASM), where the early imperial roman necropolis would be situated. $\mathrm{He}$ would again undertake extensive excavation work in this later area during the late 1970's unearthing numerous tombs dated mostly to the $1^{\text {st }}$ and $2^{\text {nd }}$ centuries $C E$, about which however very little is known (Paixão 1979, 1981; see also Gomes 2013; Viegas 2014).

If little information is available regarding these imperial funerary contexts, even less is currently known regarding the period that mediates between the latest well known pre-roman contexts, which appear to date back to the mid-4 $4^{\text {th }}$ century BCE (Arruda 1999-2000: 81 ), and the beginning of the early imperial phase, plausibly in the first decades of the $1^{\text {st }}$ century CE. The last phase(s) of the Late Iron Age and the Republican period remain poorly known even if there have been mentions in previous works of material dating to these moments (Fabião 1998: 354; see below).

The present contribution, framed in the context of an ongoing project that aims to undertake an integral study of the material from the Iron Age phases, constitutes an attempt, albeit cursory, to fill in this gap and to reconsider this poorly known period of the history of the important necropolis of Alcácer do Sal.

The revision of the collections deposited both in the National Museum of Archaeology, in Lisbon, and in the Regional Direction of Culture for Alentejo's facilities in Alcácer do Sal has in fact resulted in the identification of a considerable amount of material of Republican chronology, which warranted study as a means to better understand the later phases of the Iron Age necropolis and in particular, the process by which it became embedded in the Roman sphere after the conquest of the southern Portuguese territory.

Given the vastness of the collection of material from the site and the still ongoing nature of its study we will focus in this contribution on selected categories of ceramic material, namely black glaze pottery (BGP), amphorae and unguentaria (fig. 2). The choice of these 
categories of material results from the fact that they all offer a considerable certainty as far as their chrono-cultural setting is concerned; other pieces may belong to this same phase, but in the absence of contextual data or at least of local/regional typological studies it is impossible for the moment to establish their chronology with any degree of certainty. As for the metallic ensemble, on the other hand, and even if it does offer good perspectives for the analysis of the period in question, the current state of its study is still very preliminary and does not yet allow for a full account which we will reserve for future works.

This having been said, it must be pointed out that the classes of material studied below were also chosen because they offer particularly relevant data to address the main questions which we set forth to discuss in this contribution, namely:

1. The specific chronology of the Republican phase(s), whose definition is essential to understand if the use of the necropolis was continuous or if otherwise there were any significant hiatus in the wake of the Roman conquest;

2. The functional analysis of the Republican ensemble, which is fundamental if we are to understand the nature of the use of this area during the phase in question, a use which could either be a) funerary, continuing in the tradition of the Late Iron Age phases, or b) ritual, with the tombs of the ancestors of the growingly "Romanised" community still being visited as places of memory, identity and even cult.

In order to address these two questions, and others that derive from them, on a solid empiric basis we felt therefore that the first step was the exhaustive analysis of the available material, which is presented in the following pages. Before entering however in the specific appraisal of the studied pieces, we would like to present some further notes on the funerary topography of Alcácer do Sal as a means to better contextualize the problems analysed here.

\section{THE TOPOGRAPHY OF IRON AGE AND ROMAN ALCÁCER DO SAL AND ITS NECROPOLEIS: DATA AND PROBLEMS}

\subsection{Alcácer do Sal from the Early Iron Age to the Roman period: a brief overview}

During virtually the entire $1^{\text {st }}$ millennium BCE the settlement underlying the present day castle and city of Alcácer do Sal constituted the central node in the

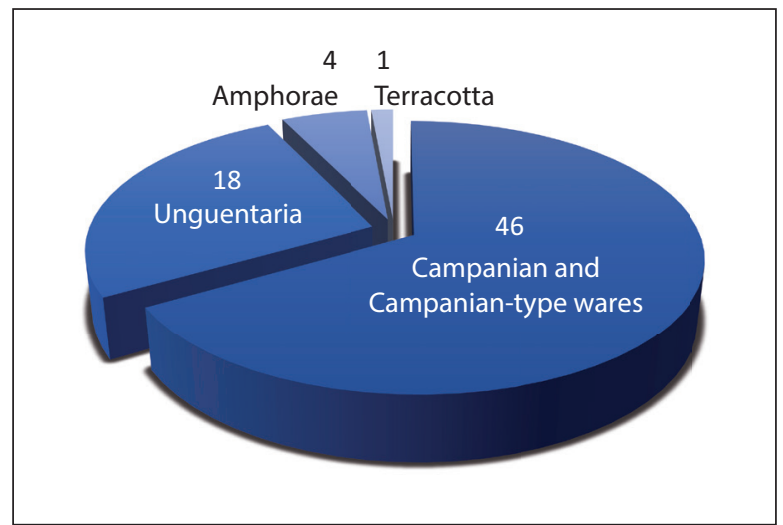

Figure 2. Sample composition (maximum number of individual vessels $=\mathrm{nmi})$.

territory of the Lower Sado basin. Occupied at least since the Late Bronze Age (Silva et al. 1980-1: 170-1), its importance during the entire span of the Iron Age is well attested not just by the rich and abundant material recovered in the necropolis (for a synthesis see Arruda 1999-2000: 72-86; also Gomes 2016) but also by a large and ever growing number of data both from the area of the castle (Silva et al. 1980-1; Arruda 19992000: 64-72; Paixão 2001; Silva 2011) and from the city's historic centre (Arruda et al. in print).

Alcácer do Sal must have been, during the whole of this period, the central node of a rather complex territorial system which probably also comprised the settlement underneath the city of Setúbal (Soares \& Silva 1986; Silva \& Coelho-Soares 2014: 309) and, during the Early Iron Age, the sites of Abul A (Mayet \& Silva 2000) and its "successor", Abul B (ibidem; Mayet \& Silva 2001). How far its influence reached the neighbouring territories is unclear, but it would be tempting to relate both the newly identified Iron Age occupations in the Arrábida hill range area (AA.VV. 2009; Arruda \& Cardoso 2013) and the "Orientalizing" influx documented in the further inland area of Ourique in the Higher Sado basin (Beirão 1986; Correia 1993; Arruda 2001) with a direct or indirect influence from Alcácer, as was already proposed, albeit in stronger terms, by J. de Alarcão (1996).

The situation of Alcácer and its territory during the last pre-roman phases and the dynamics of its inclusion in the Roman sphere remain, on the contrary, quite difficult to assess. Contexts dating to the end of the Iron Age and the Republican period were documented in the small area excavated in the castle by the team of the $\mathrm{Mu}-$ seum of Archaeology and Ethnography of the District of 
Setúbal (MAEDS) and included in their Phase V (Silva et al. 1980-1: 211-213), but apart from the actual verification of a continued sequence of occupation the limited area explored during this intervention yielded little evidence as to the nature of said occupation.

We also count with references to Republican material exhumed in other interventions in the area of the castle hill, namely in its western side (Sepúlveda et al. 2001); as for the vast area excavated in the Monastery of Nossa Senhora de Aracaeli, and even if the existence of Republican levels is mentioned (Paixão 2001: 165-6; Faria 2002: 102), very little is known as of yet. The current knowledge of the Roman Republican Alcácer is therefore very limited, and almost no indications are available as to its eventual urban layout and internal organization.

This being said, there are however relevant evidences of the continued importance of Alcácer do Sal during the first stages of the Roman presence, among which one of the most often cited and discussed is the presence of a mint (Faria 1989, 1992, 1995, 1996; Arévalo González 1998; 2012; García-Bellido \& Blázquez 2001: 333-335; Mora Serrano 2011) active from the mid- $2^{\text {nd }}$ up to the late $1^{\text {st }}$ century BCE and which issued coin with legends in a pre-roman writing system - which, controversy aside, plausibly give us the pre-roman name of Alcácer, read by A. Faria as *Beuipo (Faria 1992) - and later with the Latin legend Imp [eratoria $]$ Sal $[$ acia $]$.

Some consideration has also been given to the transition between the Pre-Roman and the Latin toponym, the suggestion having been made that the attribution of the title Imperatoria and the fixation of the official roman name of the city was due to Sextus Pompeius and dated to the period of the civil war between Caesar and the Pompeian faction (Grant 1969: 23; Faria 1999: 41-2; 2001: 75), a hypothesis that seems to have been recently questioned by new literary evidence which could suggest a higher chronology for the use of the name Salacia (Alarcão 2011: 325-6; see also Faria 2009).

Either way, these indirect evidences point to the fact that during the Republican period Alcácer do Sal maintained a considerably high status among the cities of the Hispania Ulterior and remained a regional centre of some political, administrative and eventually even military relevance, its importance also being recognized by the attribution of the ius Latii vetus possibly during the early years of the Principate of Augustus (Faria 2001: 76; Alarcão 2011: 328), and the promotion to $m u$ nicipium short thereafter (Faria 2001: 76).

The imperial phase is, on the other hand, very well documented from an archaeological point of view, with abundant contexts related to what must have been the monumental centre of the city having been unearthed in the area of the castle. These comprise what has been interpreted as a portion of the forum (Faria 1998; 2002: 90-97) - possibly a curia (Alarcão 2011: 328) - and a religious complex (Paixão 2001: 164; Faria 2002: 103113) which has been attributed to the cult of Cibeles and Attis based on the find of a by now famous tabella defixionis (Faria 2002: 105-111; Encarnação \& Faria 2001; Guerra 2003). The importance of the hill where the medieval castle was to be built, where other, smaller interventions have also yielded evidences of these imperial phases (Silva et al. 1980-1: 189-209; Sousa et al. 2008), is thus well attested.

With the administrative reorganization of the Empire Salacia became, on the other hand, the head of a civitas which appears to have encompassed the entire area of the Lower Sado, thus maintaining the articulating role it had played since the Late Bronze Age, as previously mentioned; its administrative sphere included such important nodes as the industrial complex of Tróia (Grândola) (see, among others, Étienne et al. 1994; Fabião 2009; Pinto et al. 2011) and the town of Caetobriga, underneath present day Setúbal, whose importance has become even more evident due to recent finds (Silva et al. 2010: 170-1; Silva et al. 2010) which add a more urban-like identity to the already known industrial component of the settlement (Silva \& CoelhoSoares 1980-1; Silva et al. 1986; Silva 1996).

These sites are, however, only two nodes in a territory that was intensively occupied; numerous industrial sites are known from the banks of the Sado, namely pottery kilns which have produced mostly amphorae (Mayet et al. 1996; Mayet \& Silva 1998, 2002) used as containers for the abundant industrial production of fish sauces in which the whole region seems to have been involved (see Mayet et al. 1996; Fabião 2009: 569-570), which hypothetically can be seen as depending from Alcácer do Sal, an idea that the recent revision of the data regarding the activity of the Cornelii Bocchi family (Cardoso \& Almagro-Gorbea 2011) could support.

\subsection{The funerary areas of Alcácer do Sal}

The excursus presented above, which in no means aims to synthesize the wealth of data regarding the urban layout, spatial organization and socio-economic development of Alcácer do Sal (fig. 3) during Pre-Roman and Roman times, gives us nonetheless, to some extent, a measure of the importance of this urban centre. 


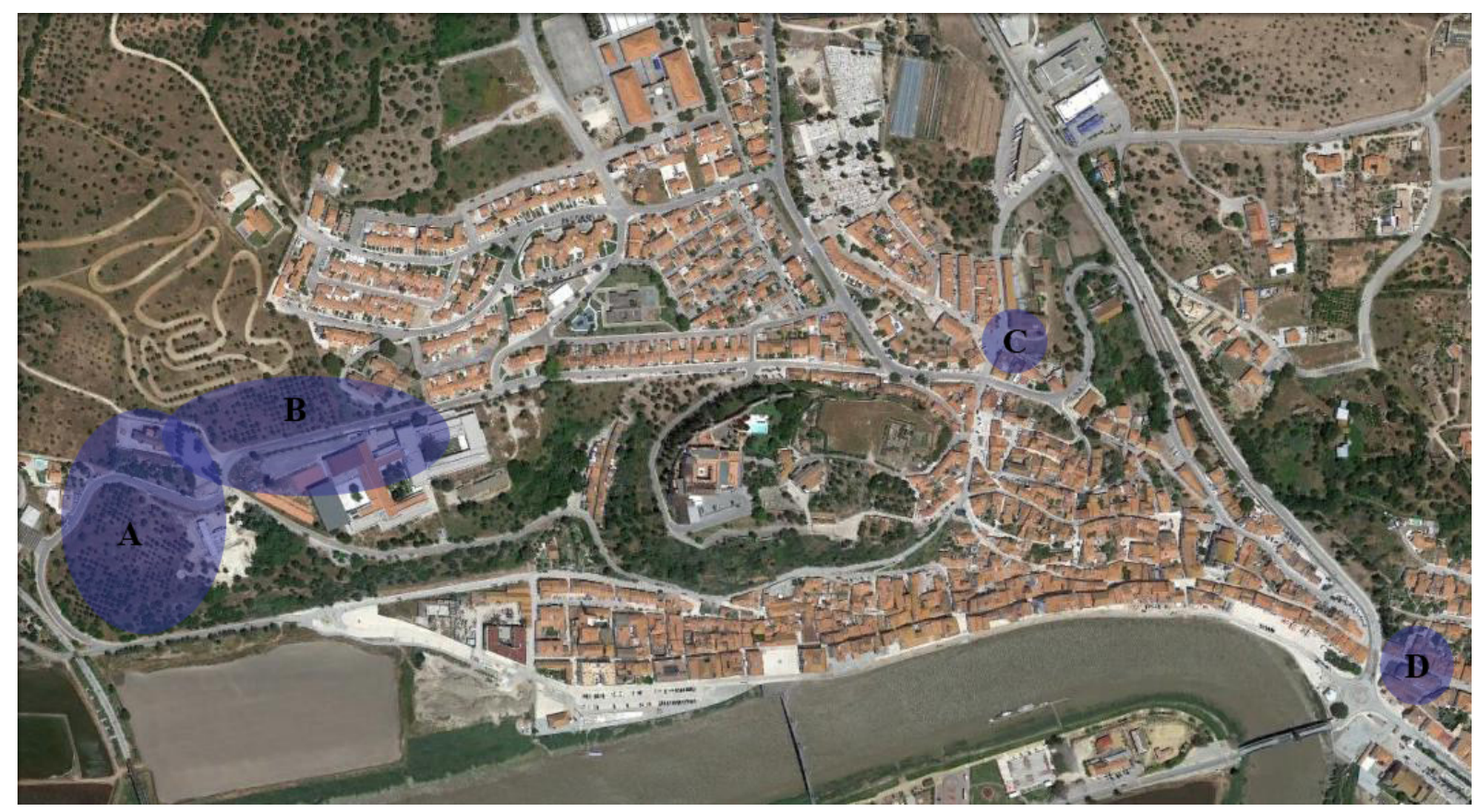

Figure 3. Approximate location of the funerary areas of Alcácer do Sal - A: Olival do Senhor dos Mártires; B: Azinhaga do Senhor dos Mártires; C: Necrópole de S. Francisco; D: Necrópole do Bairro do Crespo.

This importance, on the other hand, is also clearly illustrated by the funerary record which, however, and despite the fact that the mortuary areas have been the object of numerous and extensive interventions, is still unfortunately poorly known.

We have already mentioned above that the first data regarding the funerary areas of Alcácer were unearthed in the surroundings of the hermitage of Senhor dos Mártires in the course of agricultural works in the late $19^{\text {th }}$ century (Silva 1875; Baptista 1895). The continued, even if intermittent, archaeological study of this area during the $20^{\text {th }}$ century (Correia 1925, 1928; Paixão $1970,1979,1981,1983$ ) has yielded voluminous information regarding its sequence of use which nonetheless, due to limited publication and the progressive loss of field records, has translated into a very incomplete frame of reference with numerous gaps and uncertainties.

We will not enter here in the question of the diversity of funerary solutions used during the Iron Age nor in the problem of their stratigraphic and chronological ordering, already abundantly discussed in other contexts (Fabião 1998: 354-359; Arruda 1999-2000: 79-81; Gomes 2015); for the purposes of this contribution, and concerning the Pre-Roman phases, we will only signal two facts, one relating to topography and the other to chronology.
We know next to nothing about the layout of the Iron Age necropolis and even the precise location of the areas excavated in the $20^{\text {th }}$ century remains somewhat unclear; therefore, we only possess generic data regarding the topography of this funerary area. All indications suggest however it is mainly located to the West, East and particularly to the South of the hermitage of Senhor dos Mártires, extending to the area known as Olival da Parvoíce in the slopes that lead to the river bank. On the other hand, the Roman Imperial necropolis of ASM, recognized in the bibliography as a separated site (Paixão 1970: 92; 1979, 1981), would be situated to the North of the aforementioned hermitage.

The ongoing project for the integral study of the material pertaining to the Iron Age necropolis has clearly shown, however, that this division is far from clear; even if we are unable to attribute most pieces to any meaningful context and if the little contextual information available is impossible to confront with any concrete topographical documentation, it still became clear that there is relatively abundant material of Roman chronology in the area of the OSM (see Gomes 2013; Viegas 2014) and, reversely, some Pre-Roman material which originates in the excavations of ASM, thus suggesting the existence of at least an area of superposition between the Iron Age and the Imperial necropoleis. 
This observation does not however invalidate the fact that the main nucleus of the necropolis apparently was displaced from one period to the other; it warrants, however, the question of whether this shift was effected within a logic of continuity or after a hiatus in which this area ceased to fulfil funerary functions. This is one of the focal questions addressed in this contribution, and we will keep further observations for the final discussion below. Closely connected with this question, however, is the problem of the available chronologies for both the Pre-Roman and the Roman phases.

Concerning the Late Iron Age contexts it must be pointed out that, with the available data, it is difficult to define any funerary horizon later than the mid- $4^{\text {th }}$ century. It is however unclear if this date is indicative of sudden, or even progressive, loss of the area's funerary function, or if it is just a reflection of the absence of good chronological indicators (see below).

As for the chronology of the Imperial necropolis, most of the material remains unstudied and we can only count on the observations made by the researcher responsible for its excavation, which dates the use of the ASM from the early $1^{\text {st }}$ to the late $2^{\text {nd }} /$ early $3^{\text {rd }}$ centuries (Paixão 1979, 1981), a chronology that seems broadly confirmed by recent material studies (Gomes 2013; Viegas 2014).

Meanwhile, in what concerns the Republican period, the available knowledge, as was pointed out by $\mathrm{C}$. Fabião (1998: 354), consisted of only a few brief mentions to the existence of clearly Republican materials, namely BGP (Delgado 1971) which did in appearance exclude the existence of a hiatus during this period (Fabião 1998: 364), but a full consideration of the evidences from this phase has not until now been undertaken.

At this point of the discussion we would like to add, as a preliminary note, that all of the material from these early stages of the Roman presence that we were able to identify comes from the OSM, thus suggesting that this area was still, during this period, the main focus of activity, whether funerary or otherwise (see below).

The data from other funerary areas documented around Alcácer do Sal completes, to some extent, the panorama offered by the Senhor dos Mártires area; the assertion that «... a site with the dimensions and importance of Alcácer do Sal must have had several necropoleis and not just one» (Fabião 1998: 357, our translation) seems to have been fully vindicated by further archaeological interventions in different areas of the city which remain, however, virtually unpublished.

Another apparently important funerary area, the necropolis of São Francisco, has been identified in the area surrounding the monastery of Santo António to the North of the castle hill (Faria 2002: 63-64). Very little is known at this time about this necropolis which, however, seems to have its origins in a so far unspecified moment of the Iron Age, continuing to be used during the Republican period, as attested by the brief reference to the presence of BGP, through to the Imperial phase (Faria 2002: 63). It would be tempting to relate the foundation of this new necropolis with the apparent retraction of the use of the OSM mentioned above but with the available evidence no such assertion can be established.

Finally, and to complete this panorama, the existence of a third funerary area to the East of the urban area must be mentioned. The necropolis of Bairro do Crespo seems to have been heavily affected by construction works and the archaeological intervention undertaken there was only able to document two remaining inhumation tombs apparently dating to the $3^{\text {rd }}$ century CE (Faria \& Ferreira 1986; Faria 2002: 63). Again, it is worth noting how the available data from this necropolis suggests its development postdates the retraction of the ASM even if this fact should not be given excessive importance due to the small number of contexts excavated in this area.

\section{THE ROMAN REPUBLICAN MATERIAL FROM THE OLIVAL DO SENHOR DOS MÁRTIRES}

\subsection{Black gloss pottery (BGP) or Campanian wares}

Among the material from the OSM deposited in the National Museum of Archaeology in Lisbon and, to a lesser extent, in the facilities of the Regional Direction of Culture for Alentejo in Alcácer do Sal we were able to identify a significant number of BGP vessels (fig. 4). The inventoried ensemble comprises a total of 33 pieces (based on the maximum number of individuals [nmi], according to the Mont Beauvray protocol) which can be assigned to a specific morphology, apart from 13 other fragments of undeterminable shape, some of which have already been compiled in the seminal work of M. Delgado on the BGP in Portugal (Delgado 1971). Of the well-known universal categories we were able to document, in this ensemble, both Naples (vulgo Campanian A) and Cales and Teano productions, as well as some rare imitations presenting greyish fabrics.

For the reasons commented above there is virtually no information regarding the specific stratigraphic provenance of this material, which we can only situate 


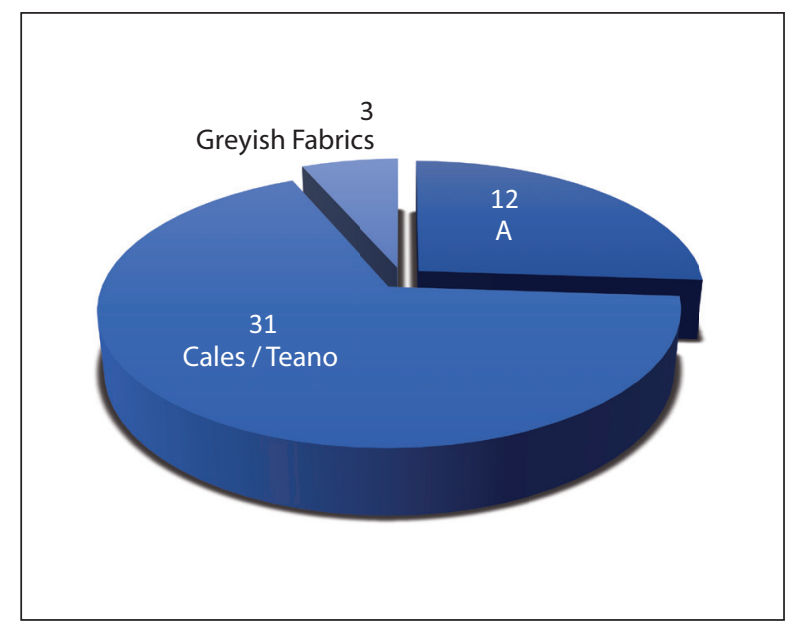

Figure 4. Composition of the Campanian ware sample (nmi).

broadly as originating in the area of the OSM. Nonetheless, its chronological significance warrants further commentary, and we will therefore address this ensemble from the point of view of its intrinsic characteristics and specificities.

The productions originating in the Naples/Ischia region (Campanian $\mathrm{A}$ ) are represented by a total of 8 pieces (fig. 5) generically characterized by the reddish tonality of the fabric. The majority of these pieces -5 vessels - present compact and pulverulent fabrics and rounded fractures accompanied by a black gloss, consistent with the Fabric 2 defined for the material from Mesas do Castelinho (Almodôvar, Portugal) (Alves 2010: 41-42); the remaining 3 examples present granular and porous fabrics, with low compaction and irregular fractures, characteristics which are similar to those of the Fabric 1 defined for that southern Portuguese site (Alves 2010: 41), being accompanied here by well-preserved lustrous black gloss with some iridescence.

The ensemble in itself is numerically diminutive and comprises little morphological diversity, but it still includes two of the shapes more commonly present in sites both from Portugal (for instances, Faro - Viegas 2010: 115 - and Monte Molião - Sousa \& Serra 2006; Dias 2015) and from the neighbouring western Andalusia (Ventura Martínez 2000: 186) with occupations dating to the $2^{\text {nd }}$ century BCE - the F1300 (Lamb. 36) patera (two examples) and the F2784 (Lamb. 27) cup (one example).

Even if the diameter of the two F1300 paterae (nn.12) couldn't be established due to their poor state of conservation, the analysis of the evolution of this shape in the western Provence and more specifically in the Olbia region (Arcelin 1978: 108; Bats 1988: 110) together

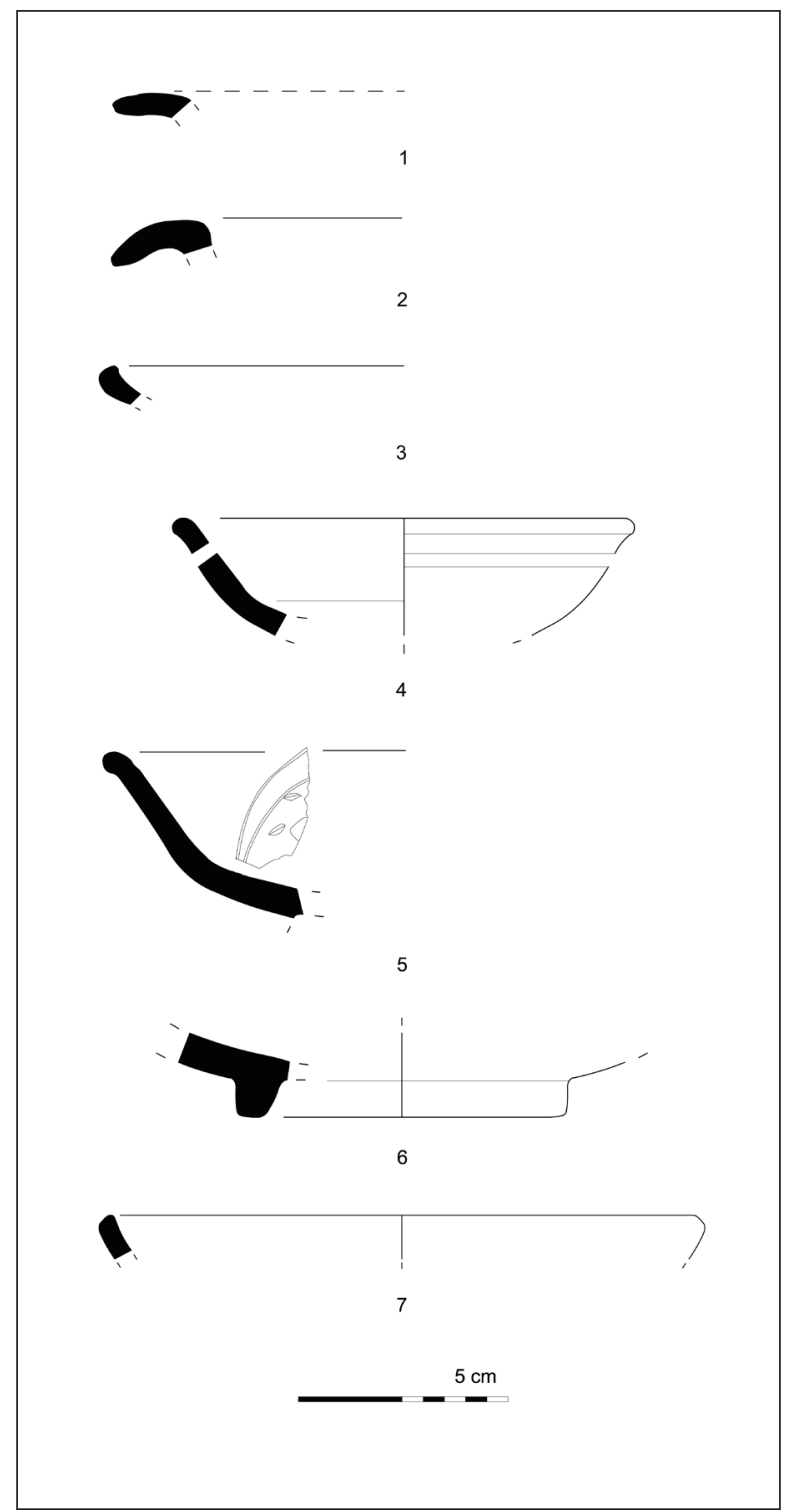

Figure 5. Campanian A wares - 1: F1300; 2: F1310 (L.36); 3: F2234 (L.55); 4,5: F2645/46 (L.28a-b); 6: F2784d (L.27a-b); 7: unidentified form.

with the data gathered in Mesas do Castelinho (Alves 2010: 55) supports the inclusion of the OSM examples in the more archaizing stages of its development. In fact, and contrary to the tendency noted for the $1^{\text {st }}$ century pieces, the rims of the vessels under study (and particularly n.2, which is the only one which allowed for a clear orientation) are rather slim, broad and pendant.

As for the piece we interpret as a F2784 cup (n.6) it corresponds to a stem similar to that compiled by J.P. Morel as P211b3 (Morel 1981: 462), in all likelihood 
pertaining to that shape and that can be dated from the second half of the $2^{\text {nd }}$ century $\mathrm{BCE}$, as illustrated by the reference bibliography used for the classification of that specific stem (ibidem).

The more characteristic shapes commented above are accompanied, on the other hand, by two specimens of F2645-46 (Lamb. 28) (nn.4-5) and a single piece belonging to the F2234 series (Lamb. 5) (n.3). Both shapes are characteristic of the Campanian A productions and their imitations, even if preferentially produced in Etruscan workshops (Morel 1981: 191), and are typical in $2^{\text {nd }}$ century BCE contexts.

One of the aforementioned F2645-46 pieces - n.5 is decorated with a stamped motive comprising leaves irregularly dispersed in a radial composition and delimited by concentric circles, reminiscent of the older variant of this class. This isolated case of decoration should be set against the backdrop of an overall tendency for the simplification of the decorative motives, which eventually disappear during the $1^{\text {st }}$ century BCE.

During the third quarter of the $2^{\text {nd }}$ century BCE, generally speaking, the printed decorations disappear giving place, still during the middle period of the class A BGP (mid-2 ${ }^{\text {nd }}$ century), to decorations comprising concentric circles, which will be typical of the class $\mathrm{B}$ wares (Aquilué Abadías et al. 2000: 401). This is well illustrated by the case of Pollentia, founded in 123 BCE, where the class A BGP presents no printed decorations at all (Sanmartí Grego et al. 2000: 145).

This decorated fragment seems to have already been illustrated by M. Delgado (1971: Est. II, n.11), but in that study the decoration was not depicted. Finally, it is worth mentioning the presence in another piece pertaining to that same shape (n.4) of an orifice which can possibly correspond to a repair mark.

Given the morphological characteristics commented above, the sample of Campanian A wares of the OSM should be included in the middle facies of these productions, with a chronology which can easily be set in the second half of the $2^{\text {nd }}$ century BCE. The presence of a vessel with a simplified decoration characteristic of the transition between the middle and the late facies of the class A BGP is in turn characteristic of a late $2^{\text {nd }}$ early $1^{\text {st }}$ century horizon.

We should stress that this interpretation stems mostly from the analysis of the represented morphologies rather than from an appreciation of the quality of the fabrics and glosses since we agree with the critics laid out by other authors regarding the overestimation of technical criteria as far as chronological attribution is concerned (Ventura Martínez 2000: 178).
On our part, we believe that certain technical traits of the fragments under study can result from post-depositional phenomena or even from their context of use, and those traits cannot therefore constitute a criterion to deny the antiquity of this ensemble since they should not supersede the indications of the morphological and decorative analysis.

These Campanian A productions constitute $26 \%$ of the documented BGP, contrasting with a vast majoritarian percentage $-66 \%$ - of productions we consider as originating in the Cales region (fig. 4).

The fabrics of the pieces we consider to be productions of this region are generically characterized by yellowish beige tonalities, by their pulverulent texture and by rounded fractures. The gloss seldom presents a good quality, as the black, thin and matte glosses are much more common, occasionally presenting evidences of pilling discs, running and finger marks.

In line with the comments made above regarding the technical aspects and the influence of post-depositional factors in the appearance of certain fabrics it should be noted that the products from Cales and their imitations in greyish fabrics are not always easy to differentiate. This difficulty results from the fact that the pieces analysed here often present firing problems evidenced by a gradation of fabric tonalities. A paradigmatic case is that of the n. 11 piece, of which one fragment would, on a first analysis, be classified as an imitation of BGP with greyish fabric; it fits, however, with another fragment which clearly corresponds to a production of the Cales workshops.

Together with such cases of firing anomalies we do not exclude that such variations could also be the result of the conditions to which the pieces were subjected during their period of use or even after their abandonment. It should not be forgotten that the archaeological site under analysis corresponds to a necropolis and the hypothesis that these vessels were deposited in contact with concentrations of ashes that might have contributed to such a variability of tonalities cannot be ignored. All these constraints force us to pay special attention and to equate all the different possibilities.

Turning now to the morphology of the pieces attributed to these productions, the shapes documented are those most typical of the peninsular contexts dating to the $1^{\text {st }}$ century BCE, a period in which, in fact, they reach their greatest diffusion. These comprise two F2320-30 cups (Lamb. 1) (nn.17-18), a F7540 pyxide (Lamb. 3) (n.19) and ten paterae which can, with more or less precision, be classified in the range of the F2250-80 species (Lamb. 5/7) (nn.8-16) (fig. 6). This last group of four species comprises different morphological details and 


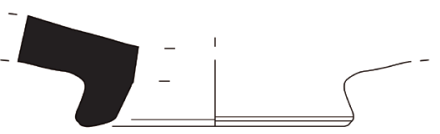

8
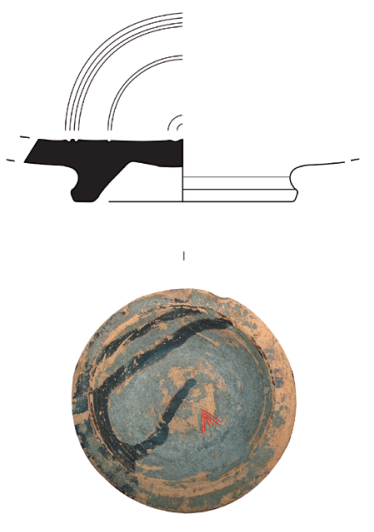

9

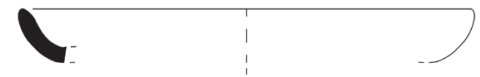

10

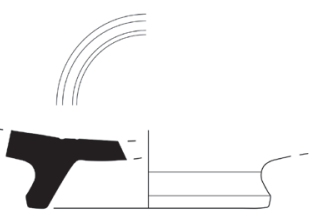

$11=23$

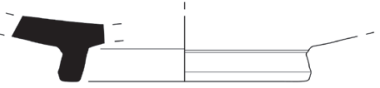

12

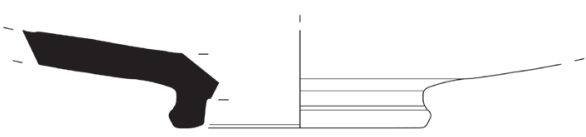

13

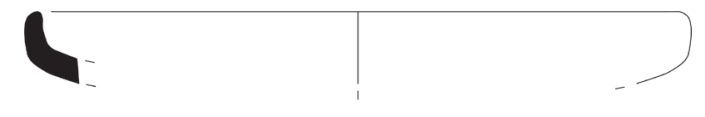

14

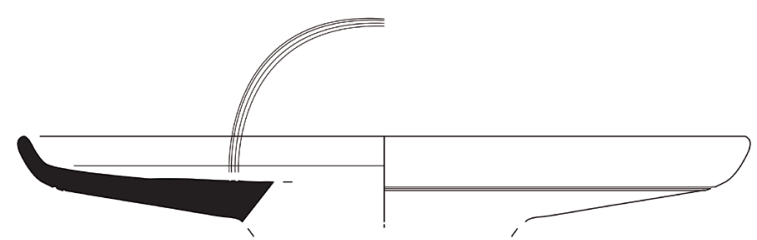

15

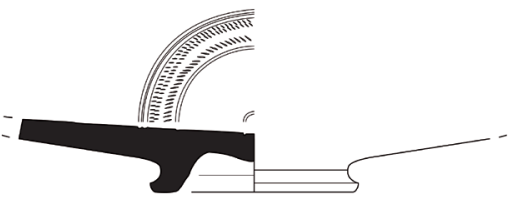

16
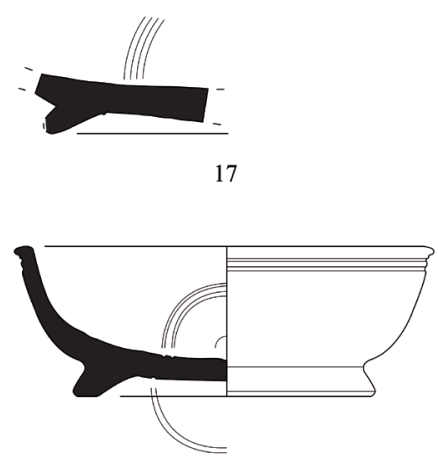

18

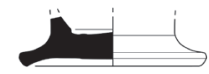

19 $5 \mathrm{~cm}$

Figure 6. Campanian wares of Cales / Teano production - 8, 9, 10: F2250-60 (L.5/7); 11=23, 2: F2250-80 (L.5/7); 13: F2280 (L.7); 14: F2265 (L.5/7); 15: F2286b (L.7); 16: F2286 (L.7); 17,18: F2323-30 (L.1); 19: F7540 (L.3). 
therefore diverse chronological specificities within the typology of J.-P. Morel (1981), but the reduced dimensions of the fragments recovered in the OSM, mostly corresponding to bases, precludes any further precisions.

Therefore, and not excluding the possibility of tracing this morphological ensemble back to the previous facies, the material under study should be attributed to the late phase of this production (Pedroni 2000: 345361 ; 2001) dated between 82 and 40 BCE.

In regard to decorative aspects, and apart from the arrow-shaped graffiti present in the external face of the base of piece n.9, we have also documented the presence of concentric circles, very common in these productions and, in one case (n.16), three rows of fine and short rouletted decoration also framed by concentric circles. This last piece was already illustrated by $\mathrm{M}$. Delgado in the 1970s (Delgado 1971: Est. II, 23).

To conclude this section regarding the productions of Cales we should make mention to the fragments nn.15-16 which share a fabric of orange tonality, very porous and with irregular fractures with abundant black and white non-plastic elements as well as a considerable amount of mica crystals. Their gloss is not homogeneous: in one case it is black and glossy with golden iridescence, showing evidences of digitations and running in the internal face of the otherwise reserved stem/ base; in the other, better preserved, it assumes a greyish coloration, matte and non-reflective.

The characteristics of their fabric, which even on a macroscopic analysis are notoriously different from those of the rest of the ensemble, authorize their attribution to a production centre probably differentiated from that of the remaining group of imports, although probably situated in the same overall geographic area (see above).

On the other hand, and even if they can be defined as pertaining to the F2286 series (Lamb. 7), the particular inflexion in an obtuse angle present in the internal face of the stem suggests some further observations. This detail, which we correlate with the Cal series (pl. 222. 17) (Morel 1981: 445), is interpreted as typical of the Etruscan productions and their imitations in a time span between the $3^{\text {rd }}$ and the $1^{\text {st }}$ century BCE. A comparison with the productions of Arezzo, with which they share certain details and which one of us (CA) has studied in the ensemble of Mesas do Castelinho, reveals that they are technically very distinct.

On the other hand, the fragments under study cannot be fitted in the so-called "vrai B" productions of Etruscan facies, and the chronology attributed to the parallel for this type of stem - exhumed in Pompey and dated to the second quarter of the $2^{\text {nd }}$ century - cannot, therefore, be extended to our piece. These considerations possibly situate our examples in a chronologically later Cales production rather than in a "...céramique arétine à vernis noir tardive" (ibidem).

Finally, this ensemble is completed by a small group of three bases, which can be included in greyish fabric productions, which imitate BGP (fig. 7). For two of these we were unable to establish their specific morphology, but the third one $-\mathrm{n} .20$ - presents a curious typology in the sense that it imitates with considerable detail the Campanian A F3131 (Lamb. 48) products which date to the second quarter of the $2^{\text {nd }}$ century BCE (Morel 1981: 249). J.-P. Morel points out that it is uncertain whether this drinking vessel reaches the $3^{\text {rd }}$ quarter of that century (ibidem). Since we believe that the arrival of these greyish fabric wares to the Portuguese territory does not, for the most part, predate the third quarter of the $1^{\text {st }}$ century BCE (Alves et al. 2014) this fact poses serious problems, given that it sets the imitation almost a century apart from the prototype.

In their original Campanian A production these pieces are rare in the republican levels of the Portuguese sites (see, for instances, Dias 2015: 105; Alves 2010: 70-71). In Cartagena this shape is attested since the first half of the $2^{\text {nd }}$ century with greyish fabrics but without gloss (Pérez Ballester 2000: 130-132), thus differing from the piece of the OSM, which presents a dark grey matte slip. Imitations of this shape in light fabric productions are also attested in Ampurias and Carthage (Morel 1981: 249, note 240).

We will return in the final discussion (see below) to the appreciation of the chronological significance of these BGP, but in a first generic appraisal this material seems to point to an early incorporation of the OSM necropolis in the Roman sphere, probably dating back to the mid- $2^{\text {nd }}$ century BCE, and also suggests a continued use throughout the Republican period, at the very least until the third quarter of the $1^{\text {st }}$ century BCE.

\subsection{Amphorae}

Apart from BGP we were also able to identify in the collections from the Olival do Senhor dos Mártires the presence of two amphorae (fig. 8) of clearly Republican chronology. The first, represented by a solid conic base (n.23), presents a fabric consistent with a production of the Tyrrhenian coast of Italy, and corresponds in all likelihood to a Greco-Italic amphora (Will 1982). The incomplete state of this vessel and the absence of 
the rim preclude any further typological specification, but if we take into consideration the overall framework of distribution of these containers in the Portuguese territory a chronology within the second half of the $2^{\text {nd }}$ century BCE for this piece seems more than likely (Fabião 1998b: 175; Arruda \& Almeida 1999: 332-333; Pimenta 2005: 119).

Other two fragments of walls of (an) amphora(e) with the same Italic provenance, very likely of the GrecoItalic or Dressel 1 types, have been documented, having been fashioned into sub-circular elements (nn.24-25) that can either be interpreted as covers for some sort of small container or otherwise as game pieces, perhaps the more common interpretation for such elements.

The second amphora documented, in this case by a fragment of rim and neck (n.26), belongs to the Mañá C2a type, and more specifically to the type 7.4.2.1 of J. Ramon (1995: 209-210); the characteristics of the fabric indicate that it corresponds to a northern African production, probably from the area of Carthage/ Tunis. This type of Central Mediterranean amphorae, although relatively common in the eastern coast of the Iberian Peninsula and in Ibiza (Ramon 1995: Mapa 79; 2008: fig. 1), has known a very limited distribution in the Atlantic shores (Arruda \& Almeida 1998: 1321-1322; Bonet Rosado et al. 2005; Arruda \& Sousa 2013: 118).

The generic chronology of this type of container is centred in the first half of the $2^{\text {nd }}$ century BCE (Ramon 1995: 209-210), even if its presence and circulation seems to have lasted until the beginning of the last quarter of that century (see, e. g., Guerrero Ayuso 1986; Díaz García 2000: 211; Ribera i Lacomba \& Marín Jordá 2003; Bonet Rosado et al. 2005) as was recently reasserted (Arruda \& Sousa 2013: 118).

\subsection{Unguentaria}

The ensemble of unguentaria (fig. 9) retrieved in the Olival do Senhor dos Mártires, albeit not very numerous - eighteen fragments, corresponding to a minimum of eleven individual vessels -, is fairly diversified, comprising examples of both fusiform and bulbous types. Within these broad typological groups we were able to document several specific types, not all however of clearly Republican chronology (see below).

These vessels are typical of funerary contexts (Anderson-Stojanović 1987: 108; Py 1993: 581; Saraçoğlu 2011), and an interpretation as containers for oils or perfumes either for use in funerary rites or deposed as grave

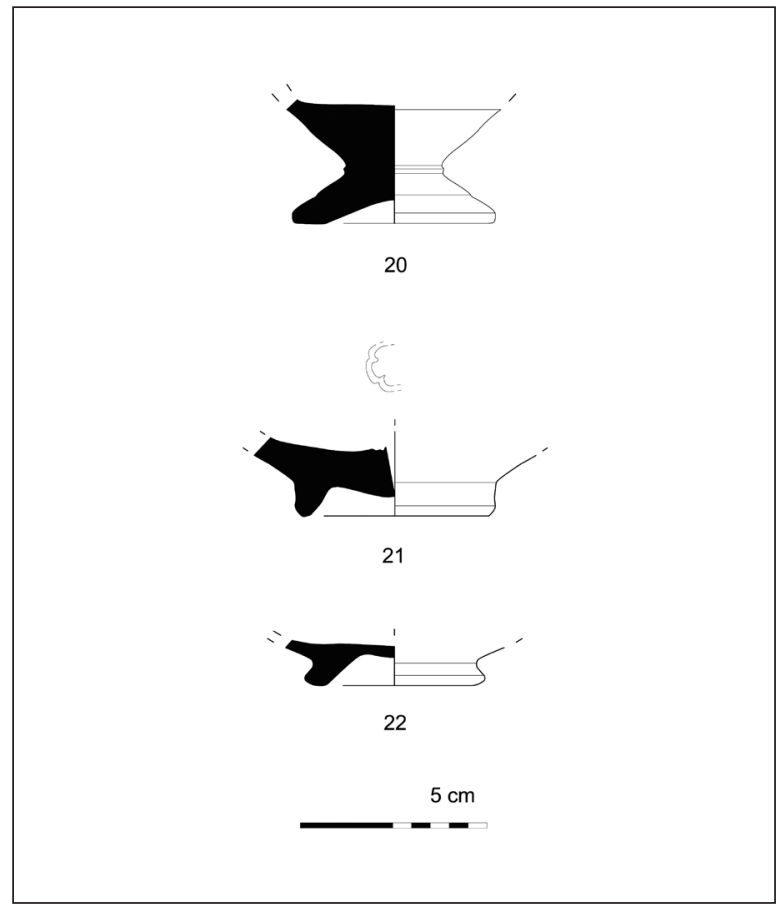

Figure 7. Campanian-type wares (greyish fabrics) - 20: F3131; 21, 22: unidentified form.

offerings is generally accepted (Anderson-Stojanović 1987: 122; see also Hübner 2006); their presence in the necropolis is, therefore, highly significant.

The earlier, fusiform types are attested by a minimum of seven individual pieces, all very incomplete. The best preserved example, n.27, presents an elongated fusiform body with a developed stem and a discreet, solid button foot. The absence of the neck and rim portion makes a specific typological attribution difficult, but its attribution to the B group defined by E. Cuadrado (1977-8: 394-396) and reprised by M. Py (1993) seems clear, as does its relation to the Republican variants within that group, in particular to Cuadrado's BIII or BV variant, which he dates to the $2^{\text {nd }}$ - early $1^{\text {st }}$ century (Cuadrado 1977-8: 394). It is also worth noting the similitude between this piece from Alcácer do Sal and the containers from Cádiz which Á. Muñoz (1987) compiles in his C group, and particularly in his C3 form, dated to the $2^{\text {nd }}$ century (Muñoz 1987: 522). Considering these parallels, a chronology within the $2^{\text {nd }}$ or the early $1^{\text {st }}$ century BCE seems likely (see also parallels in Saraçoğlu 2011: nn.29, 31).

A similar chronology could be suggested for our piece n.28, a hollow conic base with a marked central protuberance separated from the body of the container, 


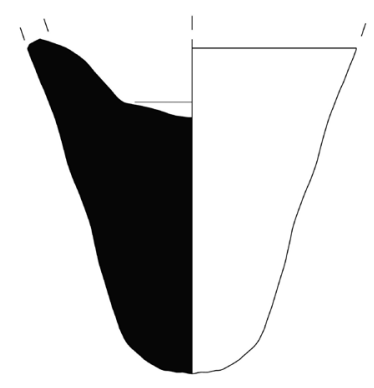

23
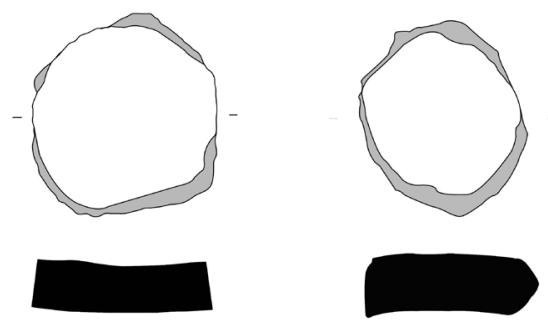

25

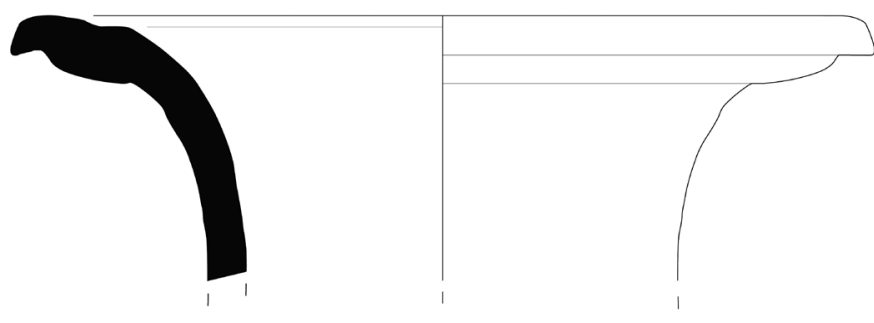

Figure 8. Amphorae - 23: base of a possible Greco-Italic amphora; 24-25: italic amphorae walls repurposed as game pieces or covers; 26: Mañá $\mathrm{C} 2 \mathrm{a}$.

equally of fusiform tendency, by a marked ridge; possibly an example of M. Py's B8 variant (Py 1993: 583), dated from the mid- $2^{\text {nd }}$ to the mid- $1^{\text {st }}$ century BCE, it can also be correlated with E. Cuadrado's BIV variant (180-100 BCE) (Cuadrado 1977-8: 394) and has particularly good parallels in pieces from the early $1^{\text {st }}$ century (Saraçoğlu 2011: n.34, with parallels; see also Robinson 1959: Pl. 2 F 49).
The remaining pieces that we can attribute to this generic typological group are small, very incomplete fragments, either of body (n.29), stem (n.30) or stem and feet (nn.31-33); their morphological characteristics are insufficient to allow any specific typological appraisal, and they can only be generally recognized as further examples of the aforementioned B group, which presents a generic chronology from the $4^{\text {th }}$ to 


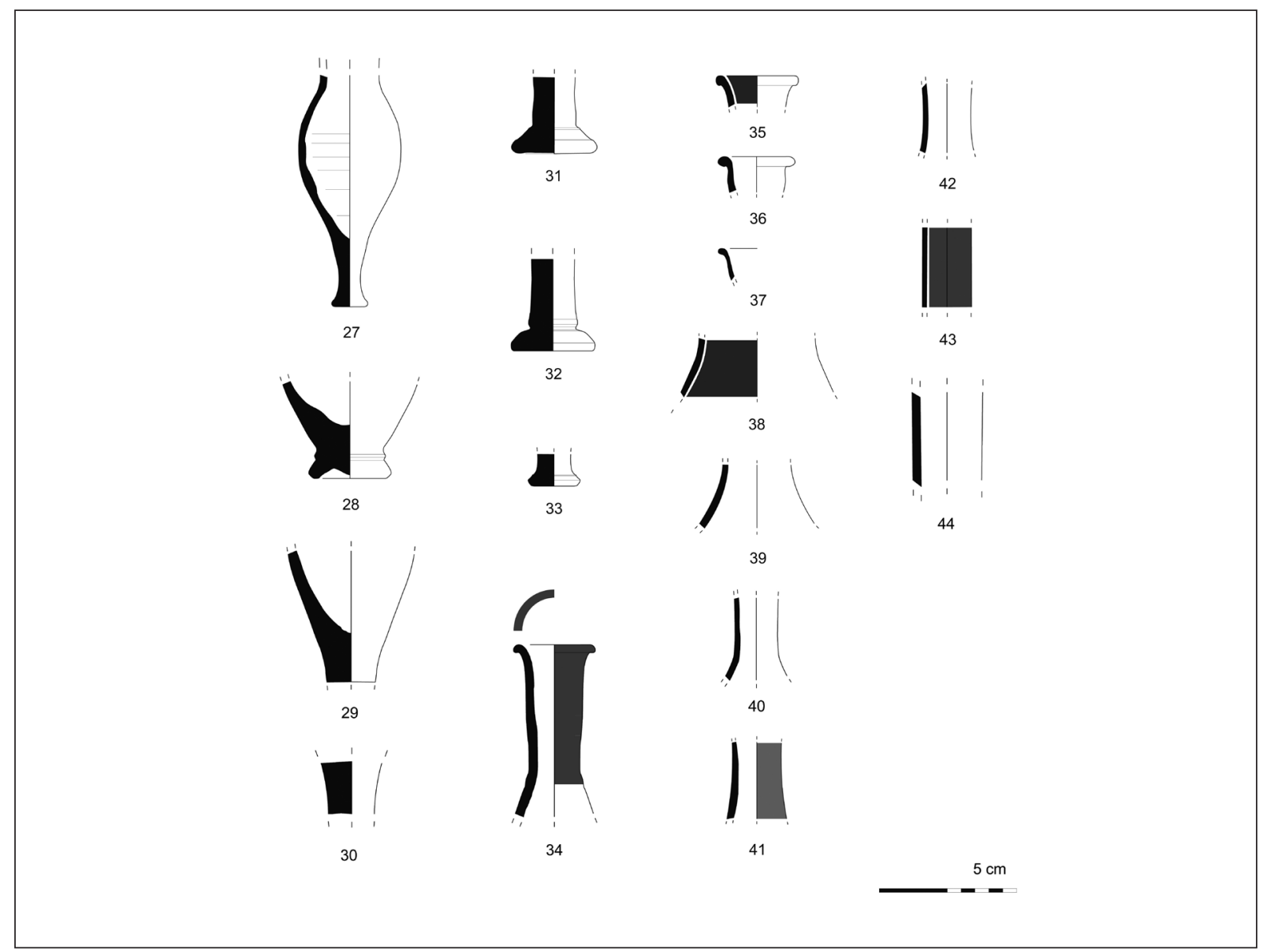

Figure 9. Unguentaria - 27: Cuadrado's BIII or BV variant; 28: Py’s B8 variant; 29-33: Cuadrado/Py's B variant; 34-37: Py's D3 variant; 38-44: unidentified forms.

the mid- $1^{\text {st }}$ century BCE (Py 1993: 582). It should however be pointed out that «...ne les recontre-t-on qu'exceptionellement à l'époque préromaine en dehors des sites grecques» (Py 1993: 581), and therefore their presence in the context we are addressing should preferably be related to the Roman presence and situated broadly between the $2^{\text {nd }}$ and the mid- $1^{\text {st }}$ century.

We find good parallels for the presence of pieces of this group in several peninsular contexts, among which we could mention the necropoleis of Ampurias (Almagro 1953: 397), of Villaricos-Baria, Almería (Almagro 1984: 206-208), of Puente de Noy, Almuñécar (Molina \& Bañon 1983), of Gibralfaro, Málaga (Martín Ruiz \& Pérez-Malumbre Landa 1999: fig. 15), of Carmona (Belén Deamos 1982) and of Cádiz (Muñoz Vicente 1987), as well as the necropolis of El Cigarralejo, Murcia (Cuadrado 1977-8: 396-398) and other Late Iberian/ Republican funerary sites (Cuadrado 1981: 63).
As for the bulbous unguentaria, represented by eleven fragments corresponding to a minimum of four individual vessels, their very inclusion in this study is problematic. In fact this type of unguentaria, included by M. Py in his D group (1993: 584), has its origins in the mid- $1^{\text {st }}$ century BCE during the late Republican period but their maximum diffusion appears to correspond to the Principate of Augustus and their use is documented all through the $1^{\text {st }}$ century CE (AndersonStojanović 1987: 110-111). Their interpretation as remains of the Republican phase in the necropolis under study is, therefore, far from secure.

Nonetheless we have chosen to include these containers in this contribution because there is, despite such reasonable doubts, a real possibility that at least some of them were used during Republican times or, at the very least, during the Augustan period, which itself apparently precedes the transference of the funerary 
centre of Salacia to the adjacent area of the Azinhaga do Senhor dos Mártires (Paixão 1979, 1981), thus providing an interesting nexus between the two funerary poles. There are, on the other hand, close parallels for the use of this type of containers in late Republican funerary contexts which seem to further justify this inclusion, albeit with all the necessary reservations.

The best preserved example of this typology, n.34, corresponds to the superior portion of a piece with the characteristic bulbous body, a tall, slightly flared neck and a simple out-turned rim; the exterior surface of the neck and rim is painted black, a trace common in containers of this type. It fits in M. Py's D3 variant, with a very broad chronology, from the mid- $1^{\text {st }}$ century BCE to the end of the $1^{\text {st }}$ century CE (Py 1993: 584), coinciding with that of the whole $\mathrm{D}$ group. The remainder of the rims we have inventoried, nn.35-37, appear to belong to very similar pieces, and the same generic classification and chronology can be extended to them.

In the interest of further narrowing down the chronological frame of these pieces it is worth noting that the use of this type of ceramic containers rapidly decreases from the Augustan period onwards due to their rapid substitution by their glass counterparts (Anderson-Stojanović 1987: 113; Py 1993: 581; Saraçoğlu 2011: note 56, passim), some of which even reproduce the morphology of the bulbous ceramic unguentaria (see Isings 1957: 4041). These glass containers are, on the other hand, well attested in the necropolis of Alcácer do Sal itself since the early decades of the $1^{\text {st }}$ century CE (Gomes 2013), thus rendering the hypothesis of such a substitution having taken place within this site at least plausible.

A close parallel for these pieces can be found in the necropolis of Rua dos Correeiros in Lisbon (Bugalhão et al. 2013) where a significant number of such containers was exhumed (Bugalhão et al. 2013: 258); once more, the overall chronology of this funerary context has been situated between the late Republic/early Principate and the mid- $1^{\text {st }}$ century $\mathrm{CE}$ (Bugalhão et al. 2013: 269), thus coinciding with the considerations expressed above.

The remaining fragments we inventoried, pertaining to portions of neck and/or body (nn.38-44) are too small and incomplete to allow for any conclusive typological adscription, although it seems very likely that they correspond to containers similar to the ones already described or to other types of analogous unguentaria.

Despite the considerable variability of the analyzed ensemble all these containers share common technological characteristics. Their fabrics are all very fine and well depurated and can be divided into two broad groups, albeit rather similar: the first presents tonalities between beige and light orange and presents no macroscopically recognizable inclusions; the second is characterized by tonalities from greyish white to light grey with very small inclusions which, when visible in a macroscopic analysis, include quartz sand and occasionally red nodules, possibly iron oxides.

In the earlier unguentaria, from the B group, both fabrics are attested while the pieces clearly pertaining to the D group belong exclusively to the second one. In the absence of further analysis, the macroscopic characterization we undertook is insufficient to establish with any documental basis the origin of these containers, especially due to the lack of studies regarding eventual production centers; it is nonetheless worth mentioning that some of the characteristics of their fabrics is reminiscent of those documented in other ceramic classes produced in the Bay of Cádiz where, on the other hand, the production of this type of container seems well attested (Muñoz Vicente 1987; Sáez Romero 2005: 148; 2008: 309-310).

\subsection{Other material}

Apart from the material commented in the previous pages there is very little else in the ceramic assemblage of the OSM that, at this point, can be directly related with its Republican phase. Naturally there is a strong possibility that among the common wares there are at least some pieces belonging to this chronological horizon, but the lack of stratigraphic context along with the absence of good regional studies of Roman Republican common wares - the exception being the ensemble of Monte Molião (Lagos) (Sousa \& Arruda 2014) which, however, pertains to a very different geographical and cultural setting - makes it nearly impossible, at this point, to individualize any such pieces from the Iron Age and/or Early Imperial assemblages.

There are, however, some other elements which could be added to this inventory. Among these, a certain relevance should be given to a terracotta figurine clearly of Hellenistic inspiration which has recently been studied (Gomes 2014). It corresponds to a kourotrophos type figure (fig. 10), very similar to a number of pieces which have been documented in the Bay of Cádiz area (Niveau \& Córdoba 2003; Corzo Sánchez 2007; Niveau 2009) and dated to the late $3^{\text {rd }}$ - early $2^{\text {nd }}$ century BCE and related with the Barcid presence and the Second Punic War.

The closest parallel to the Alcácer piece was found, however, in Mesas do Castelinho (Almodôvar) 


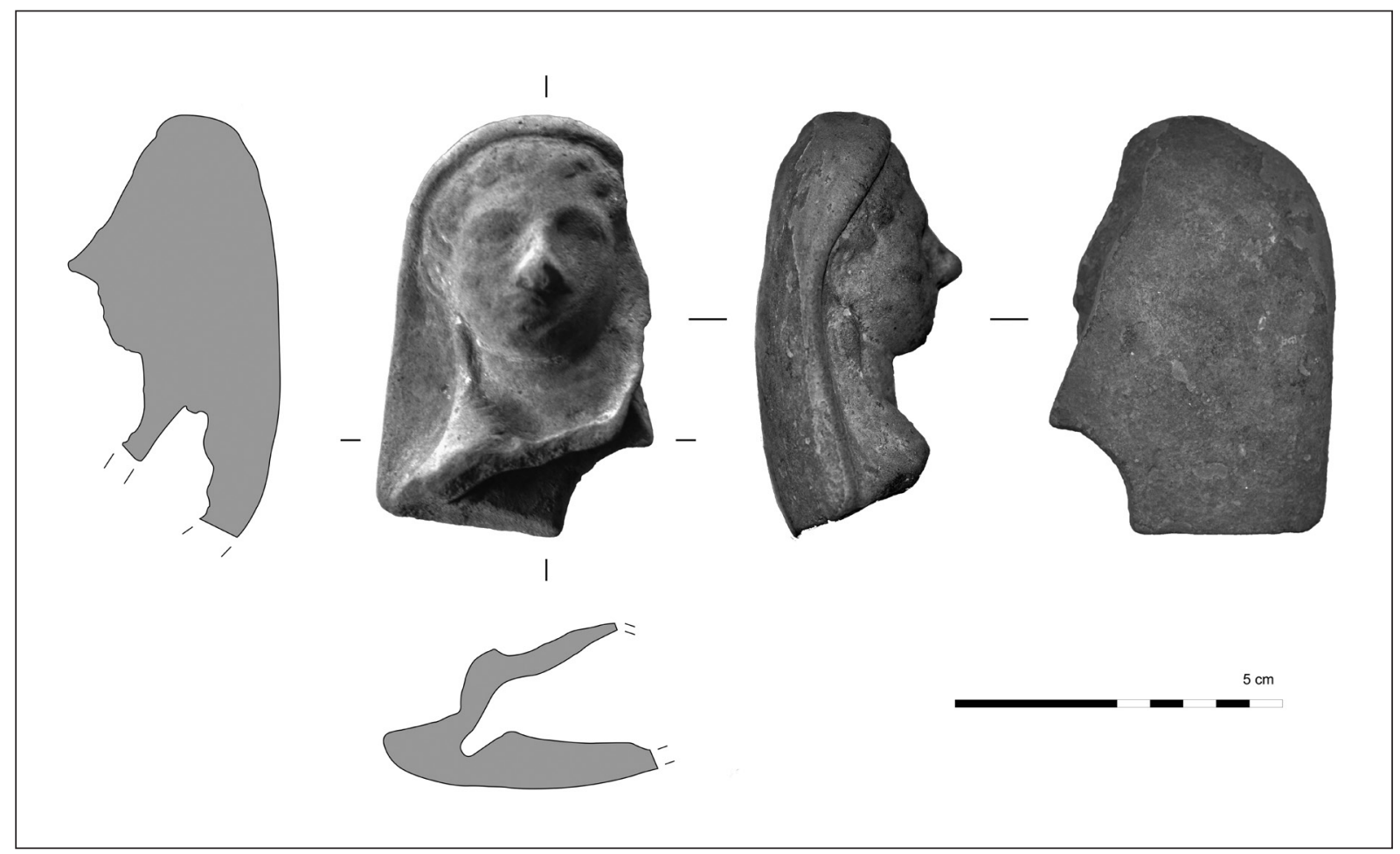

Figure 10. Terracotta representing a Hellenistic-type kourotrophos figure.

associated, among other elements, with italic imports in a deposit dated to the $2^{\text {nd }}$ century BCE (Estrela 2013). It is, therefore, fairly safe to assume that the piece of the OSM necropolis, like its counterpart from the interior of Alentejo, can be dated to a Republican phase and related to the Roman conquest of the current Portuguese territory.

Another element worthy of consideration is a lamp apparently deposited in the Municipal Museum of Alcácer do Sal (Arthur 1952: fig. 6; Almeida 1953: Est. XXX, n.1) which we haven't been able to locate so far; according to previous publications it pertains, however, to Ricci's H Type (Ricci 1973). This type of lamp, of clear Hellenistic influence, is normally dated between the mid- $2^{\text {nd }}$ and the mid- $1^{\text {st }}$ century BCE and thus represents a further attestation of the Republican phase of the necropolis under study.

This type of lamp is present in other Portuguese sites with Republican occupations, such as Santarém (Pereira 2014), Cabeça de Vaiamonte (Monforte) (Fabião 1998: 431) and Lomba do Canho (Arganil) (Nunes et al. 1990: nn.1-2). The piece from Alcácer further presents a peculiar phallic decoration in its spout which has good parallels in material from the Roman military camp of Cáceres el Viejo (Cáceres) (Ulbert 1984: nn.485-491) considered to be of italic origin, as well as, to a lesser extent, in a piece from Lomba do Canho (Nunes et al. 1990: fig. 3, n.2). An italic origin for the OSM example is also plausible.

A generic consideration of the contexts of the aforementioned parallels seems to narrow down the chronology for the circulation of this type of pieces in the western Iberian Peninsula, suggesting a probable date within the $1^{\text {st }}$ century $\mathrm{BCE}$ for the maximum diffusion of these pieces (cf. Nunes et al. 1990: 88), although an earlier presence, in particular in a coastal site such as Alcácer, cannot be excluded.

On the other hand, although with less certainty, we can attribute to this phase a fragment of a painted vessel currently deposited, like the terracotta commented above, in the Institute of Archaeology in Coimbra. It corresponds to a body fragment which does not allow for a typological integration, but both the technological characteristics of its fine, well depurated and consistent fabric and the quality of the painted decoration set it apart from the Iron Age painted wares.

It could be suggested, with the greatest possible reservations, that this fragment belonged to a kalathos, a shape which originates in the Iberian cultural area of the 
Eastern Iberian Peninsula possibly during the $3^{\text {rd }}$ century BCE (cf. Mata \& Bonet 1992: 129-130) but only seems to appear in the Atlantic façade in contexts pertaining to the Roman expansion and conquest (Muccioli 2014; Sousa \& Arruda 2014: 75), and in particular in contexts dated to the late $2^{\text {nd }}$ and early $1^{\text {st }}$ centuries BCE (ibidem). If we accept this attribution which, however, is unclear, this fragment would therefore be a further attestation of the Republican phase we have been commenting.

Finally we should also note the presence of two very small, typologically uncharacteristic fragments of fine wall wares of Italic production which, even if they offer no particular information due to their size and state of conservation, should nonetheless be related to the broad chronological horizon to which we have dedicated this survey.

\section{THE SIGNIFICANCE OF THE REPUBLICAN HORIZON OF THE OLIVAL DO SENHOR DOS MÁRTIRES}

\subsection{Chronological significance}

As we mentioned above the goal of the analysis of the Republican material from the OSM necropolis undertaken in this contribution was double: on the one hand to better understand its chronological framework and, on the other, to discuss its possible functionality and context of use. Turning first to the question of the internal chronology and phasing of the studied material, certain observations appear to be in order.

First of all, it should be noted that the material analyzed here seems to suggest that the site was integrated in the Roman sphere at a relatively early date, in the mid- $2^{\text {nd }}$ century or at least during the third quarter of that century. The amphorae presented above together with the class A BGP and at least some of the unguentaria seem to point in that sense, and demonstrate, at the very least, that there was an important frequentation of the funerary area in an early stage of the Republican period of the western Iberian Peninsula.

We would like to stress that this assertion is based, in this instance, in materials that, despite their significance, have no specific contextual coordinates, a fact that precludes the study of actual associations and therefore diminishes to some extent their informative potential. The data presented here should, therefore, be confronted and calibrated in the future by detailed studies of the Republican horizon of the settlement underlying the castle and the city of Alcácer do Sal.
The existence of relatively early Republican material in the necropolis is however quite puzzling since, as we have noted above, the final moment of use of the Iron Age necropolis has traditionally been dated to the mid- $4^{\text {th }}$ century BCE (Arruda 1999-2000: 81). It is therefore hard to explain why a local necropolis which was presumably abandoned for roughly two centuries suddenly regained a certain degree of activity with the advent of the Roman conquest.

Two different explanations can be devised for this situation. On the one hand it is possible to imagine a scenario in which the "old" necropolis suddenly became relevant in face of a new geo-political situation as the local community needed to reassert its specific roots and its ties to the territory through the evocation of the ancestors (cf. Jiménez Díez 2010). However, and despite the fact that the necropoleis were important loci of identity in the context of "Romanization" (Jiménez Díez 2006, 2008, 2010), in the case of Alcácer do Sal this explanation seems somehow too ad hoc, and another, partially complementary hypothesis should be envisaged.

This hypothesis is quite simply that the necropolis remained in use throughout the later phases of the Iron Age and actually reached the Republican period. Some arguments in favor of this continuity can be found, although their contextualization is rather problematic, as is usually the case with the OSM material.

It should be noted, first of all, that the date for the deactivation of the Iron Age necropolis has been inferred on the basis of the chronology of the well-known ensemble of Greek vases exhumed there (Rouillard et al. 1988-9). That these vases were produced and imported during the first half of the $4^{\text {th }}$ century BCE seems to be an incontrovertible fact, but the significance of this production chronology for the phasing of the necropolis should perhaps be nuanced, as it constitutes, at best, a terminus post quem for the apparent abandonment of the funerary ensemble.

It is worth remembering, on the other hand, that the question of the hoarding of prestige goods and the resulting chronological distortions has already been addressed for the necropoleis of the Iberian area of the Eastern Peninsula where it can be demonstrated that some elements, including Greek pottery, were kept for several generations before being deposited in a tomb (García Cano 1999; Jiménez Díez 2006: 71). In the absence of good contextual evidences for the OSM material, the possibility that similar phenomena may have taken place should, at the very least, be kept in mind.

This is of course a rather speculative observation, but other more concrete remarks can also concur to 


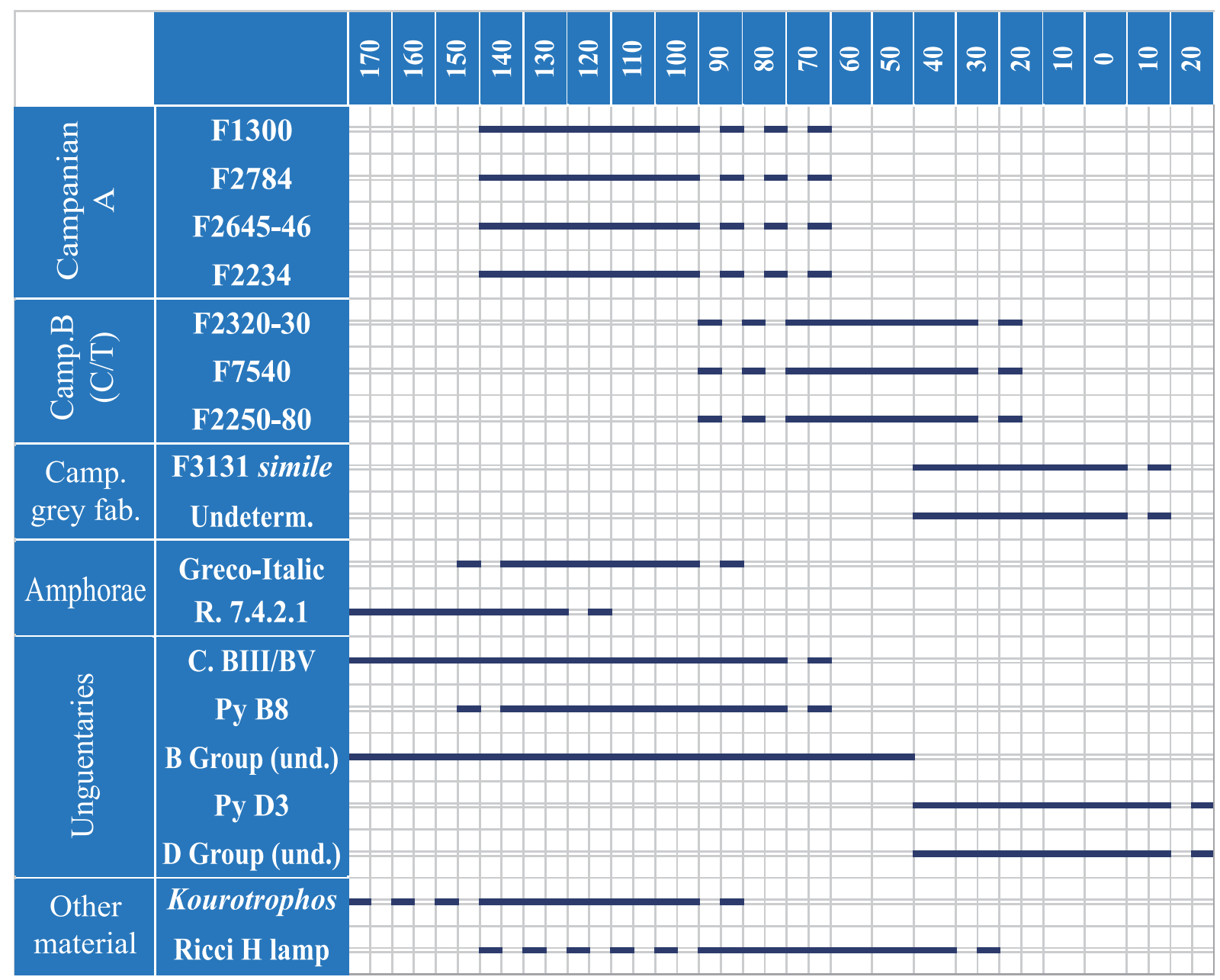

Figure 11. Chronological parameters of the material analysed.

nuance the significance of the Greek material for the establishment of the phasing of the OSM necropolis. For instance, it should be noted that the break in the supply of Greek pottery after 350 BCE is not a specificity of this site but rather a symptom of the rather abrupt decline of the overall Greek commerce in the Far West (Rouillard 1991; Arruda 1997). The apparent void of the following two centuries could therefore be an interpretive issue resulting from the sudden absence of any good "fossil-guides".

When we consider the remainder of the material ensemble of the OSM it becomes apparent, in fact, that other elements could help to obviate this problem. Even considering just the published materials it can be argued that elements such as the painted-ware urns of "Turdetanian" typology (Frankenstein 1997: Lám. 53-6), the weaponry typical of the Middle Phase of the Iberian panoply (Quesada Sanz 1997: 128-9; Fabião 1998: 361), the "Iberian-type" belt buckles (Almeida \& Ferreira 1967: nn.11-12; Schüle 1969: Tafel 108) and even some types of fibulae (Ponte 1985: 142-3) could accommodate a more dilated chronology for the funerary ensemble, bridging the apparent gap and giving a different meaning to the Republican elements studied here.

But apart from this discussion, which can only be fully resolved with the continued study of the Iron Age material and perhaps through new interventions in the site, there is a second point of interest deriving from the overall assessment of the analyzed material: the fact that, in all appearance, the use of the area of the necropolis was continuous throughout the Republican phase (fig. 11).

The ponderation of the chronological data stemming from this material does not indeed support the existence of any significant hiatus between the second 
half of the $2^{\text {nd }}$ century and the turn of the era, but rather suggests a trend of continuity which, to some extent, could establish a link - albeit tenuous - with the Imperial phase which is also well documented in this area (see Gomes 2013; Viegas 2014).

In order to further assess the nature and significance of this continued use of the funerary area of the OSM we must, however, turn to the functional analysis of the material presented in the previous pages.

\subsection{Functional significance}

As we had the opportunity to suggest in the introduction to this contribution, the functional interpretation of the Republican phase of the OSM necropolis is not a completely evident matter. Despite the well attested presence of tombs of the preceding Late Iron Age and the succeeding Early Imperial phases it would be adventurous to just extrapolate the strict funerary use of this area in those phases to the Republican period without further consideration of the intrinsic characteristics of the corresponding material.

First we should consider the BGP. Its presence in a funerary setting is exceptional for the western Iberian Peninsula, where the Republican funerary contexts remain to this day very poorly known, but it should be noted that their incorporation in the funerary repertoires of this period is well attested both in the Iberian area of the eastern Peninsula (Cuadrado 1981; García Cano et al. 1989; Jiménez Díez 2006: 69-70; for the Lower Andalusia, see also Núñez Pariente de León \& Quesada Sanz 2000: 197-200) and also marginally in some funerary contexts of Punic descent, such as Villaricos-Baria (Astruc 1951; Almagro Gorbea 1984: 213-4).

In the absence of specific contextual information it is hard to ascertain if these vessels, clearly destined to the service and consumption of food and particularly drink, were deposited in the necropolis as funerary offerings, which would imply the presence of tombs chronologically pertaining to the Republican period, or if otherwise they constitute the remains of funerary banquets or libations which do not necessarily entail new depositions, as they could be undertaken in honor of the (pre-roman) ancestors, either individual and concrete or generic and collective.

The information we can extract from the amphorae is insufficient to obviate this ambiguity. In fact, and even if the presence of the vessels commented above suggests an in situ consumption of fish paste (in the case of the T.7.4.2.1 vessel) and wine (in the case of the
Greco-Italic amphora) which would be consistent with the practice of funerary symposia (Jiménez Díez 2006: 88), this does not exclude the existence of actual burials in this period, especially if we consider that the use of amphorae as construction material in Republican tombs has been documented in other contexts (ibidem: 83).

This ambiguity does not, however, extend to the $u n$ guentaria. These elements are abundantly documented in tombs of Republican chronology, with particular incidence in the Iberian world (Cuadrado 1977-8: 396398; 1981: 63: Jiménez Díez 2006: 70) as well as in sites with a colonial ancestry, either Greek (as is the case of Ampurias - Almagro Basch, 1953) or Punic (for instances, Cádiz - Muñoz Vicente 1987 -, Carmona, in Seville - Belén Deamos 1982 -, Gibralfaro, in Málaga - Martín Ruiz \& Pérez-Malumbre Landa 1999: fig. 15 -, Puente de Noy, in Almuñécar - Molina \& Bañón 1983 - and Villaricos, in Almería - Almagro 1984: 206-208) and their function as funerary offerings seems, in this case, indisputable, giving continuity to a tradition of use of oils and essences in funerary rituals that can be traced back to the "Orientalizing" period (López Rosendo 2005; Gomes in print b).

It is our opinion that the presence of these elements strongly suggests that the OSM sheltered new funerary depositions during the Republican period, and their important testimony sheds considerable light over the other classes of material commented above. Obviously the practice of funerary banquets cannot be excluded, but if they did indeed take place then, in all likelihood, they were celebrated either during new burial ceremonies or in honor of much closer ancestors than those of the more or less remote Late Iron Age.

The information that we can extract from the remainder of the material commented earlier does not add much to this panorama. Very little can be said about the presence of the Ricci H lamp or about the putative kalathos, except that vessels of this last morphology are known to have been used as cinerary containers in Late Iron Age and Republican tombs (Presedo Velo 1982: fig. 10; Cuadrado 1987: fig. 9; Blánquez Pérez 1990: fig. 71; Alcalá Zamora 2003: fig. 58a).

The kourotrophos figure, however, does warrant some further commentaries. This representation of a nourishing deity has good parallels in the necropolis of Gadir in which similar terracotta figurines were found in non-sepulchral contexts, namely in a small shrine (Niveau \& Córdoba Alonso 2003) and in a votive well (Niveau 2009). Figurines representing similar deities, although with very different technical and visual characteristics, are also common in Iberian necropoleis 
(Horn 2011), where a good number seems to have been placed outside the tombs in deposits that can be interpreted as secondary with respect to the actual funerary deposition.

In the study one of us dedicated to the piece from the OSM (Gomes 2014) we invoked these parallels to suggest that this figurine did not necessarily originate in a tomb, but could also come from some other context related to funerary ritual and cult; we would like to retain this hypothesis here, without however denying that it could also have constituted a funerary offering.

In one case or the other the funerary significance of this figurine seems very likely as the nourishing deities also assume by extension a psychopomp function, as has been pointed out in numerous occasions (Marín Ceballos 1987: 64), protecting the deceased in the transit to the afterlife much as they have protected him/her in traversing the hardships of life.

\subsection{The OSM necropolis during the Roman Republican period}

Having considered the chronological and functional implications of the Republican material of the necropolis, we have concluded that there are considerable arguments in favor of the hypothesis of the continued use of the OSM as a burial ground during the Republican phase, possibly in continuity with a still poorly characterized mid $-4^{\text {th }}$ to mid- $2^{\text {nd }}$ century BCE phase. It should be noted, nonetheless, that the overall volume of the material studied here hardly suggests a particularly intensive use of the OSM during this period, a fact that most certainly has contributed decisively to the haziness surrounding this phase of the site.

As for the restitution of the funerary practices, rituals and landscape of the period under analysis, it remains elusive, precisely due to the lack of contextual evidence and of any reports on the excavation of Republican tombs. Some concluding remarks on those aspects can, nonetheless, be attempted.

On the subject of the funerary ritual there is little doubt that the long standing tradition of cremation remained in use under the Roman Republic. Apart from the fact that incineration is the most extended funerary treatment in strictly Roman contexts during the Late Republic (Abad Casal 2003: 78), the continued use of this rite in the cultural areas of the Iberian Peninsula where it was predominant during the Pre-Roman period, in particular in the Iberian world, is well attested (Abad Casal 2003: 81-91; Jiménez Díez 2006: 74).
As for the funerary architecture, we have no direct evidence whatsoever of the type of structure that might have received the depositions in this period. This in itself could suggest a lack of monumentality which, in turn, would be consistent with the panorama for the Late Iron Age where, even if poorly known, the tombs seem to have been fairly simple, corresponding to rather shallow graves opened in the local soil (Correia 1928). It is their shallow nature and the lack of elaborate protective structures that explain why these Late Iron Age tombs were particularly affected by the agricultural works which lead to the discovery of the necropolis in the 1870's.

The possibility that the Republican depositions were contained in structures of the same nature could help explain the poor preservation of the contexts pertaining to this period and, consequently, the dispersion of the material. This hypothesis is also consistent with the information retrieved in some Iberian necropoleis which continued in use throughout this phase, as is the case of El Cigarralejo (Murcia), where the Republican tombs corresponded to shallow pits protected by only a few stones and lacking any particular super-structure or signalization (Cuadrado 1987: 44).

As for the cinerary containers, it is difficult to assess if they existed and, if they did, what were their precise typologies. The lack of urns of specific Republican chronology could be seen as a drawback for the hypothesis we have been discussing, but the fact is that the possibility remains that the containers in use throughout this period simply emulate the traditional local types in use prior to the inclusion in the Roman sphere.

Such a situation would hardly be exceptional, as the continuity of urns of pre-roman typology is fairly generalized in other cultural areas during the Republican period (Jiménez Díez 2006: 70-1), not to mention their use even in the funerary spaces of newly founded Roman colonies (Vaquerizo 1999: 221; García Prosper et al. 2002-3), but only the continued study of the common and painted wares can help to obviate this problem.

As for the funerary gesture, little more can be added to the considerations we exposed above regarding the functionality of the material studied in these pages. The burials were, at least in some instances, accompanied by perfumes and/or unguents which no doubt also played their part in the preparation of the body and in the cremation rituals, as suggested by the presence of the unguentaria (Anderson-Stojanović 1987). The use of such substances in the funerary rituals of the necropolis is, on the other hand, attested at least since the Early Iron Age (Gomes 2013), and this particular practice can be seen as a further tread of continuity. 
The practice of food offerings and/or funerary banquets also seems very likely in the light of the presence of BGP and amphorae. Once again, this is hardly a novelty in the necropolis, as such practices seem to be well attested for previous periods (Correia 1928).

All in all, the predominant aspect of the funerary practices in the OSM necropolis during the Republican phase as suggested by the materials studied here is one of marked continuity with the local traditions, and even if many specific aspects remain to be ascertained, the impression we get from the ensemble studied in these pages is that the new elements of material culture introduced by the Roman presence were included here in practices that are deeply rooted in the local tradition.

Despite all the interpretive reserves arising from the lack of good contextual coordinates, we would argue that the few available elements of judgment suggest that in the necropolis of Alcácer, as in many others in different areas of the Iberian Peninsula, the Republican period was characterized by what has been called a "Material Romanization" (Fuentes Domínguez 1992: 589-590), as the new imported elements were organically incorporated into the on-going evolution of eminently local practices. Here, as in many other contexts (ibidem: 591), the true ideological impact of the Roman power will only be felt in the funerary sphere with the advent of Augustus, coinciding with the transference of the center of gravity of the necropolis to the adjacent area of the ASM.

\section{REFERENCES}

Abad Casal, L. (2003): “El tránsito funerario. De las formas y ritos ibéricos a la consolidación de los modelos romanos", in L. Abad Casal (ed.), De Iberia in Hispaniam: la adaptación de las sociedades ibéricas a los modelos romanos: 75-100. Alicante, Universidad de Alicante.

Alarcão, J. de (1996): “Os círculos culturais da $1^{\text {a }}$ Idade do Ferro no Sul de Portugal", in F. Villar, \& J. de Encarnação (eds.), La Hispania Prerromana. Actas del VI Coloquio sobre Lenguas y Culturas Prerromanas de la Península Ibérica: 19-36. Salamanca, Universidad de Salamanca.

Alarcão, J. de (2011): “Os Cornelii Bocchi, Tróia e Salacia”, in J. L. Cardoso, J. L. \& M. Almagro-Gorbea (eds.), Lucius Cornelius Bocchus. Escritor Lusitano da Idade da Prata da Literatura Latina: 323-347. Lisbon/Madrid, Academia Portuguesa da História/ Real Academía de la Historia.
Alcalá Zamora, L. (2003): La necrópolis Ibérica de Zamora. Madrid, Real Academia de la Historia.

Almagro Basch, M. (1953): Las necrópolis de Ampurias. Vol. I: Necrópolis griegas. Barcelona, Seix y Barral.

Almagro Gorbea, Mª J. (1984): La necrópolis de Baria (Almeria): campañas de 1975-1978. Madrid, Ministerio de Cultura.

Almeida, F. de \& Ferreira, O. da V. (1967): "Fechos e placas de cinturão, hallstáticos, encontrados em Portugal". O Arqueólogo Português 1, série 3: 81-95.

Almeida, J. A. F. de (1953): "Introdução ao estudo das lucernas romanas em Portugal". O Arqueólogo Português 2, série 2: 5-208.

Alves, C. (2010): A Cerâmica Campaniense de Mesas do Castelinho. Master Thesis. University of Lisbon, Faculty of Letters.

Alves, C.; Mataloto, R.; Soria, V. (2014): "As produções de imitação da campaniense itálica em pasta cinzenta no Sul do território actualmente português", in R. Morais, A. Fernández, M. J. Sousa (eds.), As produções cerâmicas de imitação na Hispânia. Actas do II Congresso Internacional da SECAH - EX OFFICINA HISPANA (3 a 6 Abril, 2013): 165-176. Oporto, Universidade do Porto.

Anderson-StojanoviĆ, V. (1987): "The Chronology and Function of Ceramic Unguentaria". American Journal of Archaeology 91: 105-122.

Aquilué Abadías, X.; García Roselló, J.; Guitart Duran, J. (coords.) (2000): La ceràmica de vernís negre dels segles II $i$ I a.C.: Centres productors mediterranis $i$ comercialització a la Península Ibèrica. Mataró, Museu de Mataró.

Arcelin, P. (1978): "Note sur les céramiques a vernis noir tardives en Provence Occidentale", in J. P. Morel (coord.), Journées d'étude de Montpellier sur la céramique campanienne. Archéologie en Languedoc: 105-125. Montpellier, Féderation Archéologique de l'Hérault.

Arévalo González, A. (1998): "Las acuñaciones Ibéricas meridionales, Turdetanas y de Salacia en la Hispania Ulterior", in C. Alfaro Asins, A. Arévalo González, M. Campo Díaz, F. Chaves Tristán, A. Domínguez Arranz \& P. P. Ripollés Alegre, Historia Monetaria de Hispania Antigua: 194-232. Madrid, Ed. Jesus Vico.

Arévalo González, A. (2012): "Las acuñaciones con escritura Ibérica de la Hispania Ulterior", in A. G. Sinner (ed.), La moneda de los Iberos. Ilturo y los talleres layetanos: 7-16. Solsona, Museu de l’Estampació de Premià de Mar. 
Arruda, A. M. (1997): As cerámicas áticas do Castelo de Castro Marim. Lisbon, Colibri.

Arruda, A. M. (1999-2000): Los Fenicios en Portugal. Fenicios y mundo indigena en el centro y sur de Portugal (siglos VIII-VI a.C.). Barcelona, Universidad Pompeu Fabra.

Arruda, A. M. (2001): “A Idade do Ferro pós-orientalizante no Baixo Alentejo". Revista Portuguesa de Arqueologia 4:2: 207-291.

Arruda, A. M. \& Almeida, R. R. de (1998): "As ânforas de tipo Mañá C em Portugal", in Atti del V Congresso Internazionale di Studi Fenici e Punici: 1319-1328. Marsala-Palermo, Università degli Studi di Palermo.

Arruda, A. M. \& Almeida, R. R. de (1999): “As importações de vinho itálico para o território português. Contextos, cronologias e significado", in J.-G. Gorges \& F. G. Rodríguez Martín (eds.), Économie et territoire en Lusitanie Romaine: 307-337. Madrid, Casa de Velázquez.

Arruda, A. M.; Ferreira, M.; Sousa, E. de; Lourenço, P., Lima, J. \& Carvalho, A. R. (in print): Contributos para o conhecimento da Idade do Ferro de Alcácer do Sal: os dados da Rua do Rato. Alcácer do Sal, Câmara Municipal.

Arruda, A. M. \& Sousa, E. de (2013): “Ânforas republicanas de Monte Molião (Lagos, Algarve, Portugal)". Spal 22: 101-141.

Arthur, M. de L. C. (1952): "Necrópolis de Alcácerdo-Sal (Colección del Prof. Dr. Francisco Gentil)", in Crónica del II Congreso Arqueológico Nacional: 369-380. Zaragoza, Universidad de Zaragoza.

Astruc, M. (1951): La necrópolis de Villaricos. Madrid, Ministerio de Educación Nacional.

Baptista, J. (1895): "Salacia". O Archeologo Português 4-5, série 1: 143-144.

Bats, M. (1988): Vaisselle et alimentation à Olbia de Provence (s. 350-v. 50 av. J.C.). Modèles culturels et catégories céramiques. Paris, CNRS

Beirão, C. de M. (1986): Une civilisation Protohistorique du Sud du Portugal - 1er Age du Fer. Paris, Diffusion du Boccard.

Belén Deamos, M. (1982): "Tumbas prerromanas de incineración en la necrópolis de Carmona (Sevilla)", in Homenaje a Conchita Fernández Chicarro: 269281. Madrid, Ministerio de Cultura.

Blánquez Pérez, J. (1990): La formación del mundo Ibérico en el Sureste de la Meseta. Estudio arqueológico de las necrópolis ibéricas de la provincia de Albacete. Albacete, Diputación Provincial de Albacete.
Bonet Rosado, H.; Fumadó Ortega, I.; Aranegui Gascó, C.; Vives-Ferrándiz Sánchez, J.; Hassini, H. \& Kbiri Alaoui, M. (2005): “La ocupación mauritana”, in C. Aranegui Gascó (ed.), Lixus-2. Ladera Sur. Excavaciones arqueológicas marroco-españolas en la colonia fenicia. Campañas 2000-2003: 87-140. Valencia, Universidad de Valencia.

Bugalhão, J.; Arruda, A. M.; Sousa, E. de \& Duarte, C. (2013): "Uma necrópole na praia: o cemitério romano do núcleo arqueológico da Rua dos Correeiros". Revista Portuguesa de Arqueologia 16: 243-275.

Calado, M. (2009): O Tempo do Risco. Sesimbra, Câmara Municipal.

Cardoso, J. L. \& Almagro-Gorbea, M. (eds.) (2011): Lucius Cornelius Bocchus. Escritor Lusitano da Idade da Prata da Literatura Latina. Lisbon/Madrid, Academia Portuguesa da História/Real Academia de la Historia.

Correia, V. (1925): "Uma conferência sobre a Necrópole de Alcácer do Sal". Biblos 1:7: 347-363.

Correia, V. (1928): "Escavações realizadas na Necrópole Pré-Romana de Alcácer do Sal em 1926 e 1927". O Instituto 75: 190-201.

Correia, V. H. (1993): “As necrópoles da Idade do Ferro do Sul de Portugal: arquitectura e rituais". Trabalhos de Antropologia e Etnologia 33, 3-4: 351-370.

Corzo Sánchez, R. (2007): "La coroplastia del santuario de La Algaida (Sanlúcar de Barrameda, Cádiz)", in M. C. Marín Ceballos \& F. Horn (eds.), Imagen y culto en la Iberia prerromana. En torno a los llamados "pebeteros en forma de cabeza femenina": 195-217. Seville, Universidad de Sevilla.

Cuadrado, E. (1977-8): “Ungüentarios cerámicos en el mundo ibérico. Aportación cronológica”. Archivo Español de Arqueología 50-1: 389-400.

Cuadrado, E. (1981): "Las necrópolis peninsulares en la baja época de la cultura ibérica", in La baja época de la cultura ibérica: 49-68. Madrid, Asociación Española de Amigos de la Arqueología.

Cuadrado, E. (1987): La necrópolis ibérica de El Cigarralejo (Mula, Murcia). Madrid, Real Academia de la Historia.

Delgado, M. (1971): "Cerâmica campaniense em Portugal", in Actas do II Congresso Nacional de Arqueologia: 403-424. Coimbra, Universidade de Coimbra.

Dias, V. (2015): “A cerâmica campaniense do Monte Molião, Lagos. Os hábitos de consumo no Litoral Algarvio durante os séculos II a.C. e I a.C." Spal 24: 99-128. 
Díaz García, M. (2000): “Tipocronología de los contextos cerámicos tardo-republicanos en Tarraco". Empuries 52: 201-260.

Encarnação, J. de \& Faria, J. C. (2001): “O santuário romano e a defixio de Alcácer do Sal", in J. C. Ribeiro (coord.), Religiões da Lusitânia. Loquuntur Saxa: 259-263. Lisbon, Museu Nacional de Arqueologia.

Estrela, S. (2013): "Um depósito fundacional do século II a.C. em Mesas do Castelinho (Almodôvar). Uma análise preliminar", in J. M. Arnaud, A. Martins \& C. Neves (coords.), Arqueologia em Portugal: 150 Anos: 671-679. Lisbon, Associação dos Arqueólogos Portugueses.

Étienne, R.; Makaroun, Y. \& Mayet, F. (1994): Un grand complèxe industriel à Tróia (Portugal). Paris, Diffusion du Boccard.

Fabião, C. (1998a): O Mundo Indígena e a sua Romanização na área Céltica do actual território português. PhD Thesis, University of Lisbon, Faculty of Letters.

Fabião, C. (1998b): “O vinho na Lusitânia: reflexões em torno a um problema arqueológico". Revista Portuguesa de Arqueologia 1:1: 169-198.

Fabião, C. (2009): “Cetárias, ânforas e sal: a exploração dos recursos marinhos na Lusitania". Estudos Arqueológicos de Oeiras 17: 555-594.

Faria, A. M. de (1989): "A numária de *Cantnipo". Conimbriga 28: 71-99.

Faria, A. M. de (1992): “Ainda sobre o nome pré-romano de Alcácer do Sal”. Vipasca 1: 39-41.

Faria, A. M. de (1995): "Moedas de época romana cunhadas em território actualmente português", in M. ${ }^{\mathrm{a}}$ P. García-Bellido \& R. Centeno (eds.), La moneda hispánica: ciudad y territorio: 143-154. Madrid, CSIC.

Faria, A. M. de (1996): "Emissões monetárias, Imperatoria Salacia e Caesaraugusta. Algumas questões historiográficas". Vipasca 5: 117-119.

Faria, A. M. de (1999): "Colonização e municipalização nas províncias hispano-romanas: reanálise de alguns casos polémicos". Revista Portuguesa de Arqueologia 2:2: 29-50.

Faria, A. M. de (2001): "Oppida veteris Latii Ebora, qvod item Liberalitas Ivlia, et Myrtilis ac Salacia" (Plin. Nat. 4.117). Vipasca 10: 71-82.

Faria, A. M. de (2009): “Artemidoro entre os Salakeinoi?" Revista Portuguesa de Arqueologia 12:1: 115-125.

Faria, J. C. (1998): “Algumas notas acerca do provável fórum de Salacia Imperatoria (Alcácer do Sal)". Conimbriga 37: 185-199.
Faria, J. C. (2002): Alcácer do Sal ao tempo dos Romanos. Lisbon, Colibri.

Faria, J. C. \& Ferreira, M. (1986): “Estações inéditas da época romana do concelho de Alcácer do Sal breve notícia”. Conimbriga 25: 41-51.

Frankenstein, S. (1997): Arqueología del colonialismo. El impacto fenicio y griego en el sur de la Península Ibérica y el suroeste de Alemania. Barcelona, Bellaterra.

Fuentes Domínguez, Á. (1992): "Las necrópolis ibéricas y su transformación ante la romanización", in J. Blánquez Pérez \& V. Antona del Val (eds.), II Congreso de Arqueología Ibérica: Las necrópolis: 587606. Madrid, Universidad Autónoma de Madrid.

García-Bellido, Mª P. \& Blázquez, C. (2001): Diccionario de cecas y pueblos de Hispania. Madrid, CSIC.

García Cano, C.; García Cano, J. M. \& Ruiz Valderas, E. (1989): "Las cerámicas campanienses de la necrópolis ibérica del Cabecico del Tesoro (Verdolay, Murcia)". Verdolay 1: 117-187.

García Cano, J. M. (1999): "Un aspecto poco tratado en las necrópolis ibéricas: la perduración de objetos en los ajuares: el caso de Murcia", in M.A. Valero Tévar (coord.), Primeras Jornadas de Arqueología Ibérica en Castilla-La Mancha: 169-178. Toledo. Junta de Comunidades de Castilla-La Mancha.

García Prosper, E.; Polo Cerdà, M. \& Guérin, P. (20023): "Rituales funerarios ibéricos en la necrópolis fundacional de Valentia". Anales de Arqueología Cordobesa 13-14: 279-310. Gomes, F. B. (2013a): "Vidros romanos das necrópoles de Alcácer do Sal depositados no Museu Nacional de Arqueologia", in J. M. Arnaud, A. Martins \& C. Neves (eds.), Arqueologia em Portugal: 150 anos: 813-820. Lisbon, Associação dos Arqueólogos Portugueses.

Gomes, F. B. (2013b): “As oil bottles de tipo fenício do território português e o consumo de substâncias aromáticas". O Arqueólogo Português 3, série 5: 289-310.

Gomes, F. B. (2014): "Uma terracota de estilo helenístico da necrópole do Olival do Senhor dos Mártires (Alcácer do Sal): breves notas". Conimbriga 53: 81-97.

Gomes, F. B. (2015): "The Olival do Senhor dos Mártires necropolis (Alcácer do Sal, Portugal) in the context of the Iron Age funerary practices of the Southwestern Iberian Peninsula", in L. Rocha, P. Bueno \& G. Branco (eds.), Death as Archaeology of Transition: Thoughts and Materials: 327-341. Oxford, Archaeopress.

Grant, M. (1969): From imperium to auctoritas. Cambridge, Cambridge University Press. 
Guerra, A. (2003): "Anotações ao texto da tabella defixionis de Alcácer do Sal". Revista Portuguesa de Arqueologia 6:2: 335-339.

Guerrero Ayuso, V. (1986): "Una aportación al estudio de las ánforas púnicas Mañá C". Archaeonautica 6: 147-196.

Horn, F. (2011) : Ibères, Grecs et Puniques en Extrême Occident. Les terres cuites de l'espace Ibèrique du VIIIe au IIe siècle av. J.-C. Madrid, Casa de Velázquez.

Hübner, G. (2006): "Hellenistic and Roman Unguentaria: function-related aspects of the shapes", in D. Malfitana, J. Poblome \& J. Lund (eds.), Old pottery in a new century: innovating perspectives on Roman pottery studies: 27-40. Catania: Università di Catania.

Isings, C. (1957): Roman glass from dated findings. Groningen, J. B. Wolters.

Jiménez Díez, A. (2006): “Contextos funerarios en la transición del mundo prerromano al romano en el sur peninsular". Anales de Arqueología Cordobesa 17:1: 67-98.

Jiménez Díez, A. (2008): “A Critical Approach to the Concept of Resistance: New 'Traditional' Rituals and Objects in Funerary Contexts of Roman Baetica", in C. Fenwick, M. Wiggins \& D. Wythe (eds.), TRAC 2007. Proceedings of the Seventeenth Annual Theoretical Roman Archaeology Conference: 15-30. Oxford, Oxbow.

Jiménez Díez, A. (2010): "Roman Settlements / Punic Ancestors. Some Examples from the Necropoleis of Southern Iberia", in M. dalla Riva (ed.), Meetings between Cultures in the Ancient Mediterranean. Proceedings of the 17th International Congress of Classical Archaeology (Rome 22-26 sept. 2008): 25-43. Rome, International Association for Classical Archaeology.

López Rosendo, E. (2005): "El perfume en los rituales orientalizantes de la Península Ibérica", in J. Jiménez Ávila \& S. Celestino Pérez (coords.), El Período Orientalizante I: 669-681. Madrid, CSIC.

Marín Ceballos, Ma . C. (1987): “¿Tanit en España?”. Lucentum 6: 43-80.

Martín Ruiz, J. A. \& Pérez-Malumbres Landa, A. (1999): "La necrópolis de época tardopúnica de los Campos Elíseos". Madrider Mitteilungen 40: 146-159.

Mata, C. \& Bonet, H. (1992): "Cerámica ibérica: ensayo de tipología", in Estudios de Arqueología Ibérica y Romana. Homenaje a Enrique Pla Ballester: 117-173. Valencia, Diputación de Valencia.

Mayet, F.; Schimitt, A. \& Silva, C. T. da (1996): Les amphores du Sado (Portugal). Prospection des fours et analyse du matériel. Paris, Diffusion du Boccard.
Mayet, F. \& Silva, C. T. da (1998): L'atelier d'amphores du Pinheiro (Portugal). Paris, Diffusion du Boccard.

Mayet, F. \& Silva, C. T. da (2000): Le site phénicien d'Abul: comptoir et sanctuaire. Paris, Diffusion du Boccard.

Mayet, F. \& Silva, C. T. da (2001): “O Santuário de Abul B, uma presença púnica no Baixo Sado?”, in Os Púnicos no Extremo Ocidente: 173-195. Lisbon, Universidade Aberta de Lisboa.

Mayet, F. \& Silva, C. T. da (2002): L'atelier d'amphores d'Abul (Portugal). Paris, Diffusion du Boccard.

Molina, F. \& Bañón, J. (1983): "Los ungüentarios helenísticos de la necrópolis de Puente de Noy", in Almuñécar. Arqueología e Historia: 123-130. Almuñécar, Museo Municipal de Almuñécar.

Mora Serrano, B. (2011): “Aspectos iconográficos de la numaria de *Beuipo (Alcácer do Sal)", in J. L. Cardoso \& M. Almagro-Gorbea (eds.), Lucius Cornelius Bocchus. Escritor Lusitano da Idade da Prata da Literatura Latina: 73-102. Lisbon/Madrid, Academia Portuguesa da História/Real Academia de la Historia.

Morel, J. P. (1981): Céramique campanienne: les formes. Rome, École Française de Rome.

Muccioli, G. (2014): “I kalathoi Iberici nell'estremo occidente", in Rei Cretariae Romanae Fautorum, Acta 43: 721-728. Bonn, Rei Cretariae Romanae Fautorum.

Muñóz Vicente, Á. (1987): "Avance sobre el estudio de los ungüentarios helenísticos de Cádiz”. Anuario Arqueológico de Andalucía 1986. 2: 520-525.

Niveau, A. Ma . (2009): "De Diosas Gaditanas. A propósito de un nuevo conjunto de terracotas procedente de la necrópolis de Gades". Anales de Arqueología Cordobesa 20: 35-66.

Niveau, A. Ma . \& Córdoba Alonso, I. (2003): “Algunas consideraciones sobre la religiosidad de Gadir. Nuevos datos para su estudio". Saguntum 35: 123-145.

Nunes, J. C.; Guerra, A. \& Fabião, C. (1990): “As lucernas do acampamento militar romano da Lomba do Canho (Arganil)". Conimbriga 29: 69-90.

Núñez Pariente de León, E. \& Quesada Sanz, F. (2000): "Una sepultura con armas de Baja Época Ibérica (o de época romana republicana) en la necrópolis del "Cerro de las Balas" (Écija, Sevilla)". Gladius 20: 191-220.

Olcese, G. \& Picón, M. (1998): “Ceramiche a vernice nera in Italia e analisi di laboratorio: fondamenti teorici e problemi aperti”, in C. P. Frontini e M. T. Grassi (eds.), Indagini archeometriche relative alla ceramica a vernice nera: nuovi dati sulla 
provenienza e la diffusione: 31-37. Como, Edizioni New Press.

Paixão, A. C. (1970): A necrópole do Senhor dos Mártires, Alcácer do Sal. Novos elementos para o seu estudo. Bachelor thesis. University of Lisbon, Faculty of Letters.

Paixão, A. C. (1979): "Necrópole da Azinhaga do Senhor dos Mártires". Informação Arqueológica 2: 76-79.

Paixão, A. C. (1981): "Intervenção de emergência na Necrópole romana da Azinhaga do Senhor dos Mártires - Alcácer do Sal - Distrito de Setúbal". Informação Arqueológica 4: 165-169.

Paixão, A. C. (1983): “Uma nova sepultura com escaravelho da necrópole proto-histórica do Senhor dos Mártires, Alcácer do Sal”. O Arqueólogo Português 1, série 4: 273-286.

Paixão, A. C. (2001): “Alcácer do Sal proto-histórica no contexto mediterrânico", in Os Púnicos no Extremo Ocidente: 148-172. Lisbon, Universidade Aberta de Lisboa.

Pedroni, L. (2000): "Produzione e diffusione della ceramica calena "media": problemi e ipotesi di lavoro", in X. Aquilué Abadías, J. García Roselló \& J. Guitart Durán (coords.), La ceràmica de vernís negre dels segles II i I a.C.: Centres productors mediterranis $i$ comercialització a la Península Ibèrica: 345-361. Mataró, Museo de Mataró.

Pedroni, L. (2001): Ceramica calena a vernice nera. Produzione e diffusione. Città di Castello, Petruzzi Editore.

Pereira, C. (2014): Roman Lamps of Scallabis (Santarém, Portugal). Oxford, Archaeopress.

Pérez Ballester, J. (2000): “Cerámicas de barniz negro de los niveles republicanos del anfiteatro (Cartagena)", in X. Aquilué Abadías, J. García Roselló \& J. Guitart Durán (coords.), La ceràmica de vernis negre dels segles II i I a.C.: Centres productors mediterranis i comercialització a la Península Ibèrica: 129-141. Mataró, Museo de Mataró.

Pimenta, J. (2005): As ânforas romanas do Castelo de São Jorge (Lisboa). Lisbon, IPA.

Pinto, I. V.; Magalhães, P. \& Brum, P. (2011): "O complexo industrial de Tróia desde os tempos dos Cornelii Bocchi", in J. L. Cardoso \& M. Almagro-Gorbea (eds.), Lucius Cornelius Bocchus. Escritor Lusitano da Idade da Prata da Literatura Latina: 133-167. Lisbon/Madrid, Academia Portuguesa da História/Real Academia de la Historia.

Ponte, S. da (1985): “Algumas fíbulas de Alcácer do Sal”. O Arqueólogo Português 3, série 4: 137-154.
Presedo Velo, F. J. (1982): La necrópolis de Baza. Madrid, Ministerio de Cultura.

Py, M. (1993): “Unguentariums”, in M. Py (dir.) Dicocer. Dictionnaire des céramiques antiques (VIIe $s$. av. n. è.-VIIe s. de n. è.) en Méditerranée nord-occidentale (Provence, Languedoc, Ampurdan). Lattara 6: 581-584. Lattes, Association pour la Recherche Archéologique en Languedoc Oriental.

Quesada Sanz, F. (1997): El armamento ibérico: estudio tipológico, geográfico, funcional, social y simbólico de las armas en la cultura ibérica: (siglos VI-I a.C.). Montagnac, Éditions Monique Mergoil.

Ramon Torres, J. (1995): Las ánforas fenicio-púnicas del Mediterráneo central y occidental. Barcelona, Universitat de Barcelona.

Ribera i Lacomba, A. \& Marín Jordà, C. (2003): "Las importaciones itálicas del nivel de fundación (138 a.C.) de la ciudad romana de Valentia", in Rei Cretariae Romanae Fautorum Acta 38: 287-294. Bonn, Rei Cretariae Romanae Fautorum.

Ribera i Lacomba, A. (coord.) (2013): Manual de céramica romana. Del mundo Helenístico al Imperio Romano. Alcalá de Henares, MARCM.

Ricci, M. (1973): "Per una cronologia delle lucerne tardorepublicane". Rivista di Studi Liguri 39: 168-234.

Robinson, H. S. (1959): The Athenian Agora 5. Pottery of the Roman Period. Chronology. Athens/Princeton, American School at Athens.

Rouillard, P. (1991): Les Grecs et la Péninsule Ibérique $d u$ VIIIe au IVe siècle av. J.-C. Paris, Diffusion du Boccard.

Rouillard, P. ; Paixão, A. C. ; Villanueva-Puig, M.-C. \& Durand, J.-L. (1988-9): "Les vases grecques d'Alcácer do Sal”. O Arqueólogo Português 6-7, série 4: 43-108.

Sáez Romero, A. (2005): “Aproximación a la tipología de la cerámica común púnico-gadirita de los ss. IIIII’. Spal 14: 145-178.

Sáez Romero, A. (2008): La producción cerámica en Gadir en época tardopúnica (siglos -III/-I). Oxford, Archaeopress.

Sanmartí Grego, E.; Principal, J. (2000): “Les Ceràmiques campanianes tardanes. Algunes impressions a partir de la fácies documentada a Pollentia", in X. Aquilué Abadías, J. García Roselló \& J. Guitart Durán (coords.), La ceràmica de vernís negre dels segles II i I a.C.: Centres productors mediterranis I comercialització a la Península Ibèrica, 145-147. Mataró, Museu de Mataró.

Saraçoğlu, A. (2011): "Hellenistic and Roman unguentaria from the necropolis of Tralleis". AnadolouAnatolia 37: 1-42. 
Schüle, W. (1969): Die Meseta-kulturen der Iberischen Halbinsel. Berlin, De Gruyter.

Sepúlveda, E.; Sousa, É. M. de; Faria, J. C. \& Ferreira, M. (2001): "Cerâmicas romanas do lado ocidental do castelo de Alcácer do Sal, 2: 'cerâmicas de verniz negro' e cinzentas". O Arqueólogo Português 19, série 4: 199-234.

Silva, C. T. da (1996): "Produção de ânforas na área urbana de Setúbal", in Ocupação romana dos estuários do Tejo e do Sado. Actas das $1^{a}$ S Jornadas sobre Romanização dos Estuários do Tejo e do Sado: 43-54. Seixal: Câmara Municipal.

Silva, C. T. da (2011): "No Baixo Sado, da presença fenícia à Imperatoria Salacia", in J. L. Cardoso \& M. Almagro-Gorbea (eds.), Lucius Cornelius Bocchus. Escritor Lusitano da Idade da Prata da Literatura Latina: 57-71. Lisbon/Madrid, Academia Portuguesa da História, Real Academia de la Historia.

Silva, C. T. da \& Coelho-Soares, A. (1980-1): “A Praça do Bocage (Setúbal) na Época Romana. Escavações arqueológicas de 1980". Setúbal Arqueológica 6-7: 249-284.

Silva, C. T. da \& Coelho-Soares, A. (2014): "Preexistências de Setúbal. A ocupação da Época Romana da Travessa de Manuel Galo, n's 4-4B", in II Encontro Nacional de Arqueologia da Arrábida. Homenagem a A. I. Marques da Costa: 305-338. Setúbal, MAEDS.

Silva, C. T. da; Coelho-Soares, A. \& Soares, J. (1986): "Fábrica de salga da época romana da Travessa de Frei Gaspar (Setúbal)", in Actas do I Encontro Nacional de Arqueologia Urbana (Setúbal, 1985): 155-159. Setúbal/Lisbon, IPPC.

Silva, C. T. da; Soares, J.; Coelho-Soares, A.; Duarte, S. \& Godinho, R. (2010): "Preexistencias de Setúbal. $2^{\mathrm{a}}$ campanha de escavações arqueológicas na Rua Francisco Augusto Flamengo, $n^{\circ}$ s 10-12. Da Idade do Ferro ao Período Medieval". Musa 4: 161-214.

Silva, C. T. da; Soares, J. \& Wrench, L. N. C. (2010): "Les premières mosaïques romaines découvertes a Caetobriga (Setúbal, Portugal)", in M. Şahin (ed.), 11th International Colloquium on Ancient Mosaics: 295-308. Istanbul, University of Istanbul.

Silva, J. N. P. da (1875): "Uma necrópolis romana em Portugal". Boletim da Real Associação dos Architectos Civis e Archeologos Portugueses 6, tomo 1: 91.

Soares, J. \& Silva, C. T. da (1986): “Ocupação préromana de Setúbal: escavações arqueológicas na Travessa dos Apóstolos", in Actas do I Encontro Nacional de Arqueologia Urbana (Setúbal, 1985): 87-101. Setúbal/Lisbon, IPPC.

Sousa, É. M. de; Sepúlveda, E.; Faria, J. C. \& Ferreira, M. (2008): "Cerâmicas romanas do lado ocidental do castelo de Alcácer do Sal, 6: conclusões". Revista Portuguesa de Arqueologia 11:1: 149-161.

Sousa, E. de \& Arruda, A. M. (2014): “A cerâmica comum romano-republicana de Monte Molião (Lagos)". Onoba 2: 55-90.

Sousa, E. de \& Serra, M. (2006): "Resultados das Intervenções Arqueológicas realizadas na zona de protecção de Monte Molião (Lagos)". Xelb 6: 11-26.

Ulbert, G. (1984): Caceres el Viejo. Ein spätrepublikanisches Legionslager in Spanisch-Extremadura. Mainz, Philipp von Zabern.

Vaquerizo, D. (1999): La cultura ibérica en Córdoba: un ensayo de sintesis. Córdoba, Universidad de Córdoba.

Ventura Martínez, J.J. (2000): "La cerámica de barniz negro de los siglos II-I a.C. en Andalucía occidental", in X. Aquilué Abadías, J. García Roselló \& J. Guitart Durán (coords.), La ceràmica de vernís negre dels segles II $i$ I a.C.: Centres productors mediterranis i comercialització a la Península Ibèrica: 177-215. Mataró, Museo de Mataró.

Viegas, C. (2010): A ocupação romana do Algarve. Lisbon, UNIARQ.

Viegas, C. (2014): "Terra sigillata imports in Salacia (Alcácer do Sal, Portugal)", in Rei Cretariae Romanae Fautorum, Acta 43: 755-764. Bonn, Rei Cretariae Romanae Fautorum.

Will, E. L. (1982): “Greco-Italic Amphoras”. Hesperia 51: 338-356. 